\title{
Effect of single/dual monitor use on the behavior of neck- shoulder musculature
}

\author{
Rabab T. Alabdulmohsen \\ West Virginia University
}

Follow this and additional works at: https://researchrepository.wvu.edu/etd

\section{Recommended Citation}

Alabdulmohsen, Rabab T., "Effect of single/dual monitor use on the behavior of neck-shoulder musculature" (2011). Graduate Theses, Dissertations, and Problem Reports. 2272.

https://researchrepository.wvu.edu/etd/2272

This Thesis is protected by copyright and/or related rights. It has been brought to you by the The Research Repository @ WVU with permission from the rights-holder(s). You are free to use this Thesis in any way that is permitted by the copyright and related rights legislation that applies to your use. For other uses you must obtain permission from the rights-holder(s) directly, unless additional rights are indicated by a Creative Commons license in the record and/ or on the work itself. This Thesis has been accepted for inclusion in WVU Graduate Theses, Dissertations, and Problem Reports collection by an authorized administrator of The Research Repository @ WVU. For more information, please contact researchrepository@mail.wvu.edu. 


\title{
Effect of single/dual monitor use on the behavior of neck-shoulder musculature
}

\author{
Rabab T. Alabdulmohsen \\ Thesis submitted to the \\ College of Engineering and Mineral Resources \\ At West Virginia University \\ in partial fulfillment of the requirements \\ for the degree of \\ Master of Science \\ in \\ Industrial Hygiene
}

Ashish D. Nimbarte, Ph.D., Chair

John Etherton, Ph.D.

Steve E. Guffey, Ph.D.

Department of Industrial and Management System Engineering

\author{
Morgantown, West Virginia
}

2011

Key words: video display unit; dual screen monitor; electromyography of neck and shoulder muscles; head and neck 3D kinematics

Copyright 2011 Rabab T. Alabdulmohsen 


\title{
Abstract \\ Effect of single/dual monitor use on the behavior of neck-shoulder musculature
}

\author{
Rabab T. Alabdulmohsen
}

The design and functionality of the computer or video display unit (VDU) workstation has continuously evolved since its advent. One of the recent developments in the design of VDU workstations that may affect working postures of the head and neck and the activity of corresponding musculature is the use of dual screen monitors. VDU workstations with dual screen monitors are becoming increasing common at offices, libraries, and many other workplaces. A few studies show that user performance and efficiency is positively affected by the use of dual screen monitors, however, currently effect of dual screen monitors on the overall behavior of the neck and shoulder region is unknown. Therefore, this study was aimed at understanding the effect of use of dual screen monitors VDU workstation on the biomechanical behavior of the neck and shoulder musculature. A laboratory study was performed to compare the effect of dual and single screen VDU workstation on the 3D head and neck postures and neck muscles activities. Nine healthy participants were recruited for this study. Each participant performed three types of tasks: (1) reading for ten minutes; (2) typing for five minutes; and (3) search and find tasks for ten minutes using single and dual screen monitors. The results of the present study have showed that user adopted asymmetrical, more rotated, head and neck postures while working with dual screen monitors. Working postures and muscle activity pattern with respect to the monitor layout were found to depend on the type of the task. Typing task elicited higher postural and muscle activity load followed by search and find, and reading tasks. Independent of the tasks, right sternocleidomastoid muscle showed higher activity levels for dual screen layout. This increased activity level may be due to increased head rotation associated with the dual screen monitors. 


\section{Acknowledgements}

I would like to express my sincere gratitude and deep appreciation to Dr. Ashish Nimbarte, my major advisor, for his guidance, invaluable recommendation, encouragement, understanding and wisdom. He was never lacking in kindness and support. Without his support this thesis would not have been a reality.

I would also like to extend my appreciation to my committee members, Dr. Steve Guffey and Dr. John Etherton, for their valuable suggestion on improving the quality of this thesis and for their teaching and advice during my graduate studies at West Virginia University. I wish to thank all my participants for their time, patience and cooperation.

I am indebted to my husband Mohammed for his love, encouragement and support which inspired me to reach this goal. Finally, I dedicate this thesis to my lovely kids Rakan, Ghassan and Kamal. They have always provided me love and are indubitably the source of my strength and confidence. 


\section{Table of Contents}

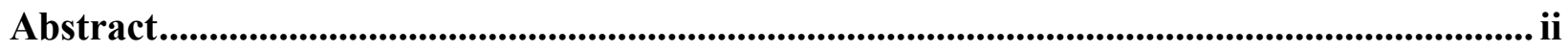

Acknowledgements ............................................................................................................................ii

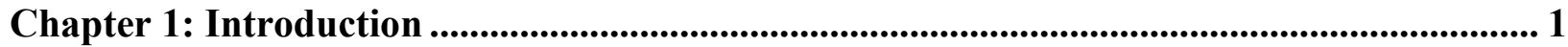

Chapter 2: Literature review .......................................................................................... 4

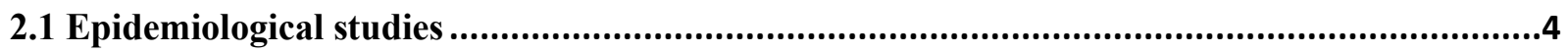

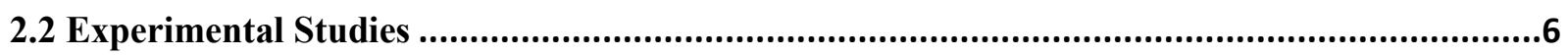

2.3 Recent changes in the VDU workstation............................................................................

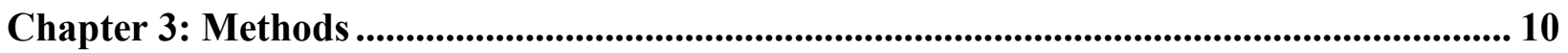

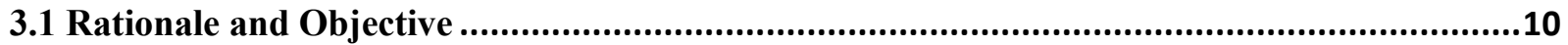

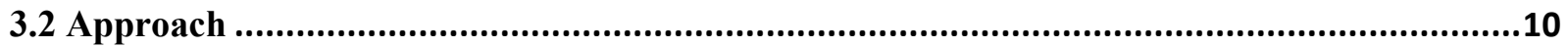

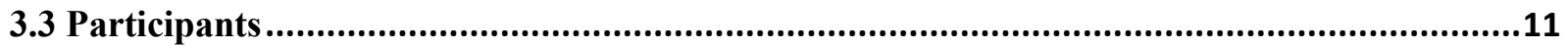

3.4 Apparatus

3.4.1 Electromyography system ...........................................................................................11

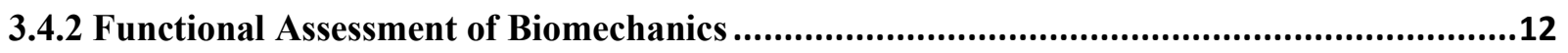

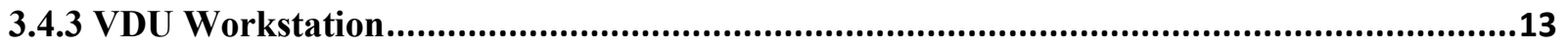

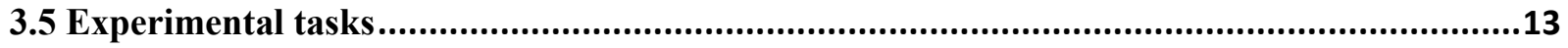

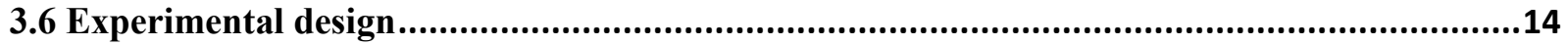

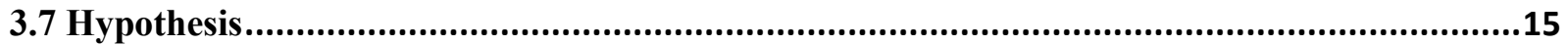

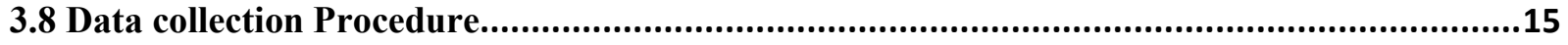

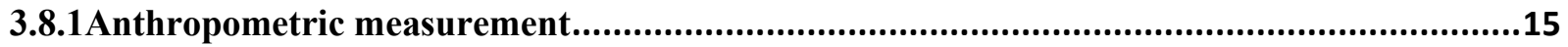

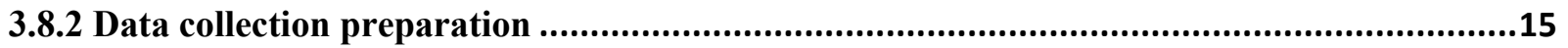

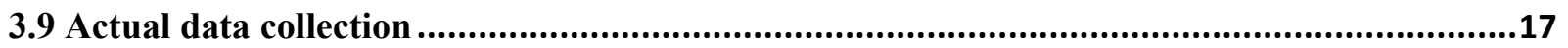

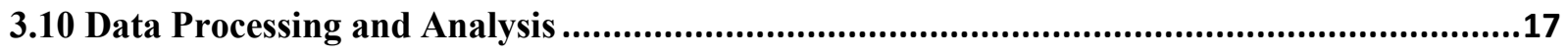

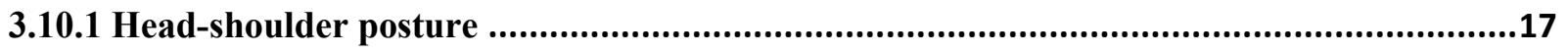

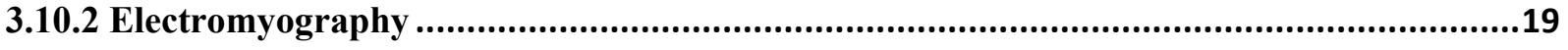

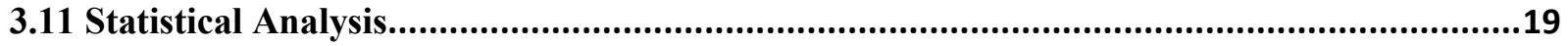

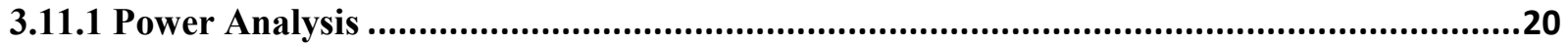

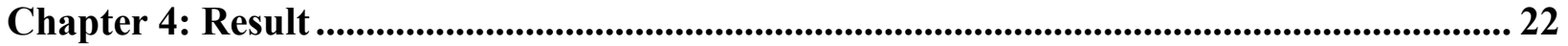

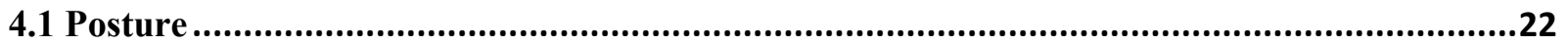

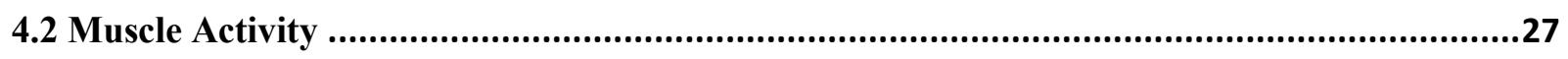

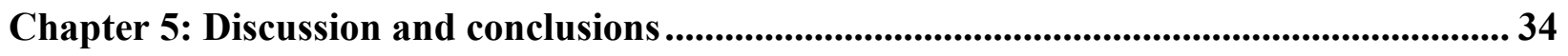

5.1 Limitations and recommendation for future studies: .........................................................39 


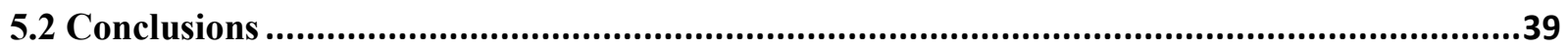

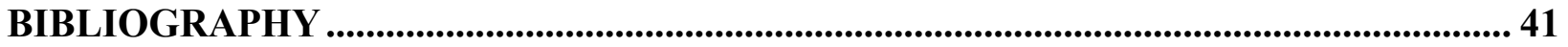

Appendix A - Consent form...................................................................................................... 44

Appendix B - Computer program used for calculating postural loads................................. 49

Appendix C - Normal probability plot of residuals ......................................................... 63

Appendix D - Raw postural load Data ............................................................................................65

Appendix E - Raw normalized muscle activity data ................................................... 66 


\section{LIST OF TABLES}

Table 3.1 Loading scores used for the quantifying the posture load index...................18

Table 4.1 ANOVA table for postural load by the cervical flexion, bending, and rotation........23

Table 4.2 Mean (SD) of the postural load by cervical flexion, bending and rotation............25

Table 4.3 ANOVA table for N-MAV of the sternocleidomastoid muscles.....................28

Table 4.4: Mean (SD) of the normalized muscle activity during the reading, search and find, and

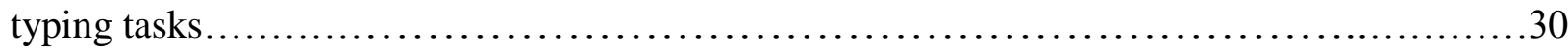

Table 4.5 ANOVA table for N-MAV of the cervical trapezius muscles......................30 


\section{LIST OF FIGURES}

Figure 3.1:Telemyo 2400 electromyography system consisting of (A) Telemyo 2400T transmitter, pre-amplified lead wires,(B) PC-interface receiver, and(C) disposable, self-adhesive $\mathrm{Ag} / \mathrm{AgCl}$ snap electrodes.

Figure 3.2 Functional assessments of biomechanics (FAB) system. .13

Figure 3.3 Top views of the two monitor screen layouts. Layout 1 is a single screen monitor

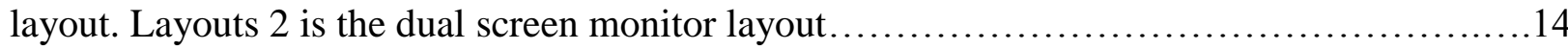

Figure 3.4 Experimental workstation............................................ 17

Figure 4.1 Overall postural load by (A) cervical flexion; (B) cervical bending; (C) cervical rotation as a function of type of tasks and monitor layouts..............................24

Figure 4.2: Flexion and bending postures used by the user during the typing, search and find and reading tasks. .26

Figure 4.3: Overall trend of the cervical rotation during typing, search and find and reading tasks

Figure 4.4: Normalized activity of the sternocleidomastoid muscles .29

Figure 4.5: Normalized activity of the cervical trapezius muscles .32 


\section{Chapter 1: Introduction}

In the recent years, growth in information technology has made use of computers or video display units (VDU) at modern offices a basic necessity. Not only employees in modern offices use computers to a major part of the day, but also the people in general, are becoming highly dependent on the computers for most day to day activities such as social networking, shopping, banking, travel booking, etc. According to the Bureau of Labor Statistics, in United States, 77 million workers use computers at work, which constitute $55.5 \%$ of the total employment (BLS, 2005). In a different study by the Australian Bureau of Statistics, nearly 78\% of the population was reported to have computer access at home (Australian Bureau of Statistics, 2005).

The physical demand of computer work may seem relatively low in terms of forces and moments; but excessive use of computers had led to a number of health and occupational problems. One of the consequences of sustained computer use is the increased prevalence of neck and shoulder musculoskeletal disorders among the VDU users (Francisco, 1992; Gerr et al., 1996; Gerr et al., 2002). In USA, an annual incidence rate of neck-shoulder MSD of 58\% and a prevalence rate of up to $62 \%$ was reported for VDU users (Gerr et al., 2002; Jensen et al., 2002). Some specific disorders that are typically associated with the low level sustained force demand during the computer use are the neck and shoulder pain syndromes such as trapezius myalgia, tension neck syndrome and cervicalgia (Juul-Kristensen et al., 2006). The occupational groups that are more severely affected by musculoskeletal disorders with regard to prolonged use of computers include office secretaries, data entry workers, and call center employees (Kothiyal and Bjonerem, 2007). 
VDU users often perform seated tasks for long durations that cause static loading of the neck and upper extremities (Turville et al., 1998a). From a human machine perspective, keyboard and mouse of a VDU workstation are considered as the primary input devices, and the monitor screen is considered as the output device. While physical aspects of a well-designed workstation such as arm rest, mouse pad, keyboard stand, provide sufficient support to the body parts used in operating input devices, the postural fixation of the head and neck region is primarily governed by placement of the output device (i.e., the monitor). The position of the head and neck is extremely important in setting the preferred viewing angle with respect to the monitor screen. Awkward head neck postures (forward head/neck) adopted during the VDU use are known to be the risk factors for neck pain among the VDU users (Chiu et al., 2002; Szeto et al., 2002). Some studies also provide an evidence for a relationship between musculoskeletal symptoms of neck and shoulder with the increased cervical extension (Aarås et al., 2001; Marcus et al., 2002) or flexion (Ariëns et al., 2001) caused by high or low levels of monitor placements, respectively. Thus, monitor placement is a key facet of the VDU workstation design. General guidelines developed by International Organization for Standardization (ISO, 1992) and Australian Standards (AS, 1990), and National Institute of Occupational Safety and Health (NIOSH, 1999) recommend a visual envelope of 0 to 60 degrees below eye level as optimum viewing zone for monitor placement. Specific epidemiological research, lab-based experiments, and field investigations recommend different positions within the extreme locations suggested by the standards. A comprehensive review of these studies is presented in the literature review chapter. One of the recent developments in the design of a VDU workstation with respect to the monitor screen is the increased use of dual screen monitors at various workplaces. Dual screen monitors are claimed to have positive effect on the efficiency of the workers. However, currently 
it is unknown how working on a VDU workstation with dual screen monitor affects the biomechanical and physiological behavior of the neck and shoulder musculature. 


\section{Chapter 2: Literature review}

Growing concern about the physical impact of computer use has led to a number of epidemiological, lab-based, and field investigations that explore musculoskeletal effect of VDU use. In this chapter previous research that primarily focuses on the neck and shoulder MSD among the VDU users are reviewed.

\subsection{Epidemiological studies}

Musculoskeletal discomfort, especially in the neck and shoulder region, was listed as the main occupational health concern for the people who work with the VDU in a number of studies. Gerr et al.,(2002) conducted a prospective study performed over a duration of three years using newly hired employees from eight big firms in metropolitan Atlanta $(n=632)$. These employees on an average spent more than 15 hours/ week working with computers. Neck-shoulder and hand-arm musculoskeletal symptoms were found to be common among the computer user with an annual incident rate of 58 and 39 cases/100 person-year, respectively. Korhonen et al., (2003) reported an incidence rate of $34.4 \%$ for neck pain among the VDU employees in three administrative units of a medium-sized city in Finland $(n=515)$. Sillanpaa et al., (2003) performed a study using survey questionnaire to estimate the prevalence of musculoskeletal symptoms and disorders among full-time VDU users. Three types of VDU users, office workers $(n=298)$, customer service workers $(n=238)$, and designers $(n=247)$, participated in this study. The results for all the occupations combined showed that the prevalence of musculoskeletal symptoms in the neck were most common followed by shoulders, elbows, lower arms and wrists, and fingers. The corresponding prevalence rates were $63 \%, 24 \%, 18 \%, 35 \%$ and $16 \%$, respectively. Woods (2005) performed a study to estimate the prevalence of musculoskeletal 
pain/discomfort and visual strain symptoms among data processing VDU workers. A questionnaire was used to collect discomfort data from the VDU workers $(n=175)$ and the control group ( $\mathrm{n}=129$ ) in the same organization. Eighty-six percent of the VDU workers reported musculoskeletal pain/discomfort, with the highest prevalence rate of $58 \%$ for the neck pain. More recently, Johnston et al., (2008) found in cross-sectional survey study that mild level of neck pain was experienced by $53 \%$ of the of female office workers $(n=333)$.

The risk factors for MSD of the neck and upper extremity among the computer users can be classified into following four categories:

(1) Individual factors: age, gender, obesity, physical activity, smoking habits, use of vision correction, and inherent psychological states (Johnston et al., (2008)

(2) Physical workstation design factors: position of computer monitors, method, type and location of other input devices such as keyboard and mouse (Punnett and Bergqvist, 1997)

(3) Task demand factors: duration of computer use, frequency of breaks (Punnett and Bergqvist, 1997)

(4) Workplace psychosocial factors (Ariëns et al., 2001; Johnston et al., 2008)

Among the workstation design factors, placement of computer monitor is the one of the most frequently identified risk factor for neck and shoulder pain among the VDU users. Bergqvist et al., (1995) conducted a cross sectional study using a sample of 260 computer users. Among the workstation design variables, higher monitor placements was linked with the neck MSD among the VDU users. Higher monitor placement was also listed as the risk factors for neck and upper extremity musculoskeletal symptoms in the computer users by Cook et al., (2000) based on a cross sectional study ( $n=270$ ). Psihogios et al., (2001) found that in the field setting, workers 
spend 60 to $80 \%$ of the time looking at the computer monitor and the perceived discomfort in the neck is related with the monitor placement. In a different field investigation, Fostervold et al., (2006) found that the discomfort in the neck and shoulder was significantly affected by the placement of the monitors. Ariens et al.,(2001) stated that neck flexion and rotation in the seated work postures commonly adopted by the office workers can result in neck pain and Black et al., (1996) found that sitting postures with excessive cervical flexion is associated with the neck pain.

\subsection{Experimental Studies}

Considering the importance of the location and height of display screen in overall VDU workstation design and its impact on musculoskeletal symptoms and disorders among the VDU users, several laboratory studies have looked at effect of different monitor configurations on the behavior of neck shoulder region.

Villanueva et al., (1997) studied effect of VDU screen heights on the changes in the body postures and the EMG activity of the neck muscles during a non-keyboard task. Ten healthy subjects performed mouse-driven interactive task at the screen heights of 80,100 and 120 centimeters above a standard height desk. The postural analysis showed that at higher screen heights, neck became significantly more erect and subjects adopted a more backward leaning trunk position. EMG activity of the neck-shoulder muscles was associated with the neck angles. Increased neck extensor muscle activity was found to be related with the flexed neck postures adopted while using low level monitor screen.

The relationship between head and neck posture and VDU screen heights was also studied by Kietrys et al.,(1998). Two screen heights (38 in and 43 in) were studied. Twentyseven participants (three male, 24 female) participated in this study. Subjects were photographed 
over two 10-minute periods and cervical spine flexion angles were recorded using goniometers. The results of this study show that an elevated position of the VDU screen significantly increased the upper cervical angle due to increased extension of the head relative to the neck. Turville et al., (1998b) also examined the effect of two VDU screen locations $\left(15^{\circ}\right.$ and $40^{\circ}$ below horizontal eye level) on the activities of neck muscles, head/ neck posture, heart rate and operator performance. Five male and seven female from North Carolina University population participated in this study. Participants performed reading and typing tasks using the different monitor configurations. Low level VDT location $\left(40^{\circ}\right.$ below horizontal eye level) demonstrated significantly greater head tilt angles and elevated muscle activity levels for the neck muscles. No considerable differences in the operator performance or heart rate were noticed as a result of changes in the monitor locations. Seven of the 12 subjects preferred the $15^{\circ}$ monitor position. In a similar type of study, Burgess-Limerick et al., (1999) evaluated the influence of eye level and low level monitor locations on the head and neck postures. Twelve subjects from the university population performed a document correction task for 30 minutes. Low level monitor condition were found to be associated with a higher degrees of neck flexion.

In addition to the monitor location, Sommerich et al., (2001b) examined the effect of monitor size and participant characteristics on the loading of neck and mid-back muscles. Eight touch typists and non-touch typists performed six experimental trials using three viewing angles $\left(0^{\circ}, 17.5^{\circ}\right.$, and $35^{\circ}$ below the horizontal eye level) and two monitor sizes (14 in and $\left.19 \mathrm{in}\right)$. Muscle activities were found to be generally higher for the low viewing angle, 14 inch monitor size, and for non-touch typists. Participant preferred the midlevel placement $\left(17.5^{\circ}\right.$ below the horizontal eye level). 
The relationship between the monitor placement and chair type on the risk factors associated with developing musculoskeletal pain/discomfort of the back and neck were evaluated by Babski-Reeves et al., (2005). Eight subjects (four male and four female) performed 2 hours of standard data entry tasks using different combinations of monitor height (low and high) and chair types (high and low cost). The ineteraction between the monitor height and chair type was significant for neck and back muscles. For the neck muscles, the lowest level of activity was observed for high monitor position combined with high cost chair.

Recently, Szeto and Sham (2008) studied effect of angled position of display screen on the activity of neck and shoulder stabilizing muscles. Twenty university students performed typing task for 20 minutes using central, angled left, and angles right screen positions. Angled positions showed higher level of activities for the cervical spinae and upper trapezius muscles. Kothiyal and Bjornerem (2009) looked at the effect of computer monitor setting on the muscular activity, user comfort and acceptability. Ten subjects performed typing task for 10 minutes using three monitor settings $\left(15^{\circ}, 30^{\circ}\right.$, and $45^{\circ}$ below horizontal at eye level). Results of this study indicate that muscle activity data were not significantly different between the different monitor settings. However, comfort and acceptability data show that high monitor setting was most preferable among the participants of this study.

\subsection{Recent changes in the VDU workstation}

The design and functionality of the computer workstation has continuously evolved since its advent. One recent development which may significant affect the working postures, especially of the head and neck region, is the use of dual screen monitors. VDU workstations with dual screen monitors are becoming increasing common at offices, libraries and many other workplaces. A few researchers have looked at the effect of dual screen monitors on the efficiency 
and overall productivity of the users. Tobler and Anderson (2004) conducted a study to compare the effect of single and dual screen monitors use on the user performance. In this study, 108 university and non-university personnel performed various computer operations using single screen, multi-screen and multi-screen with hydravision display monitors. Participants performed simulated office tasks that involved editing slide shows, spreadsheets and text documents. Performance (including task time, number of errors made) and usability (learning ease, time to productivity, quickness of recovery from mistakes, ease of task tracking,) measures were significantly higher for the multi-screens displays. In another study, Russell and Wong (2005) investigated the effect of dual-screen monitors on task organization, ease of use, and productivity. A self-administered questionnaire survey was used to collect information from 17 employees working at University Libraries. All respondents agreed that dual-screen monitors were very easy to use. Additionally, all participants responded that their individual productivity and efficiency had increased with the addition of a second monitor screen since it often allowed them to combine or delete steps required to complete a certain task. 


\section{Chapter 3: Methods}

\subsection{Rationale and Objective}

The findings of literature review show that neck and shoulder MSD are highly prevalent among the computer or VDU user. Epidemiological studies divide the risk factors for MSD of the neck and upper extremity among the computer users into four categories: (1) individual; (2) workstation design related; (3) task demand related; and (4) workplace psychosocial factors. Variables associated with the computer monitor placement, such as height, location, and size, etc. were identified as the key facets of workstation design in a number of epidemiological studies, lab-based experiments, and field investigations, because of their influence on neuromuscular and biomechanical behavior of the neck and shoulder region. Recent advancements in the computer processors and hardware have made use of multiple screen monitors easy and economical. VDU with dual screen monitors are becoming increasingly common at a number of workplaces. Although, two of studies show that user performance and efficiency is positively affected by the use of dual screen monitors, the effect of dual screen monitors on overall behavior of the neck and shoulder region is still largely. Therefore, this study was aimed at understanding the effect of use of dual screen monitors VDU workstation on the biomechanical behavior of the neck and shoulder region.

\subsection{Approach}

A laboratory study was performed to compare the effect of dual screen monitor VDU workstation and a single screen monitor on the 3D head and neck postures and neck muscles activities. Functional Assessment of Biomechanics (FAB) system was used to measure changes in the 3D head neck postures. The activities of neck muscles were measured using Electromyography (EMG) system. 


\subsection{Participants}

Nine healthy subjects between the ages of 21 to 40 years were recruited for this study. Before the data collection, the experimental procedures and possible risks associated with the study were explained to the participants and their signatures were obtained on a consent form approved by the Institutional Review Board at West Virginia University (Appendix A). The primary inclusion exclusion criteria used in this study were:

1) at least two years of experience working with VDU workstation

2) user spends more than $60 \%$ of time at work, working on a VDU

3) free from any type of musculoskeletal disorders

\subsection{Apparatus}

\subsubsection{Electromyography system}

Telemyo 2400 Electromyography system (Noraxon Inc., AZ, USA) is a 16 channel telemetry EMG system consisting of Telemyo 2400T transmitter, pre-amplified lead wires, PCinterface receiver, and disposable, self-adhesive $\mathrm{Ag} / \mathrm{AgCl}$ snap electrodes (figure 3.1). The bipolar $\mathrm{Ag} / \mathrm{AgCl}$ pre-gelled surface electrodes $(1 \mathrm{~cm}$ diameter, interelectrode distance is $2 \mathrm{~cm}$ ) connect to Telemyo 2400T transmitter via pre-amplified lead wires. The pre amplifier on the lead wires have a band-pass of 10-1000 Hz (gain 500), CMRR >100 dB, Input Impedance >100 $\mathrm{M} \Omega$. The Telemyo 2400T transmitter was mounted on the participants using a pouch and belt clip. This transmitter transmits data wirelessly to the PC-interface receiver connected to the host computer. The frequency of EMG data acquisition was set at $1000 \mathrm{~Hz}$. 


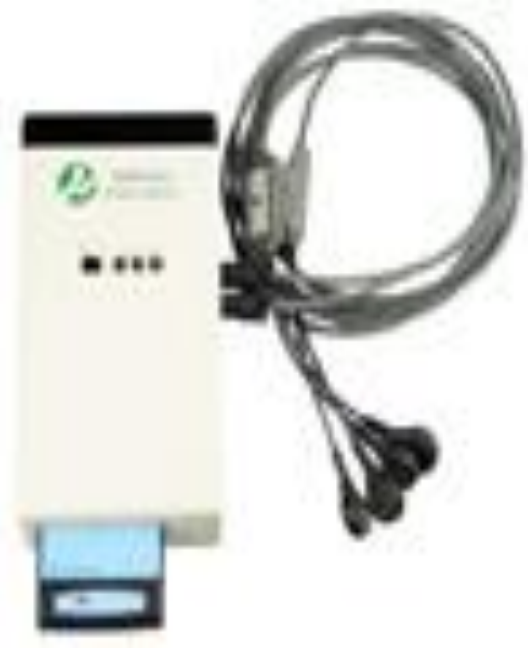

(A)

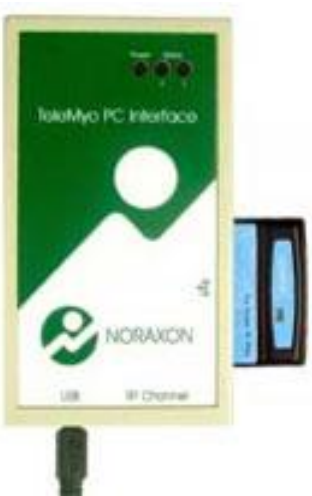

(B)

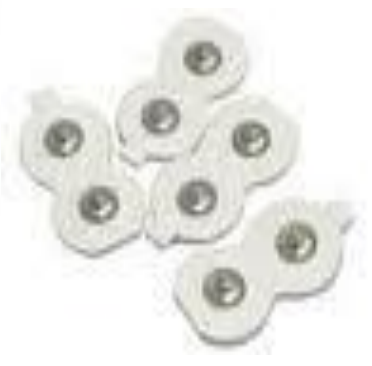

(C)

Figure 3.1: Telemyo 2400 electromyography system consisting of (A) Telemyo 2400T transmitter, pre-amplified lead wires,(B) PC-interface receiver, and(C) disposable, self-adhesive Ag/AgCl snap electrodes.

\subsubsection{Functional Assessment of Biomechanics}

Functional Assessment of Biomechanics (FAB) (BIOSYN, Canada) system is a full body 3D kinematic system. It consists of 13 small, light weight sensors $(4 \times 7 \times 2.4 \mathrm{~cm})$, that goes on the selectable body segments of the user (figure 3.2). Each sensor has a triad of accelerometers, gyrometer and magnetometer that allows real time detection of angular displacement within biomechanical bodies. This is a completely wireless system that transmits the 3D posture data to

a host computer using a dedicated wireless network. The posture data was acquired at a frequency of $100 \mathrm{~Hz}$. 


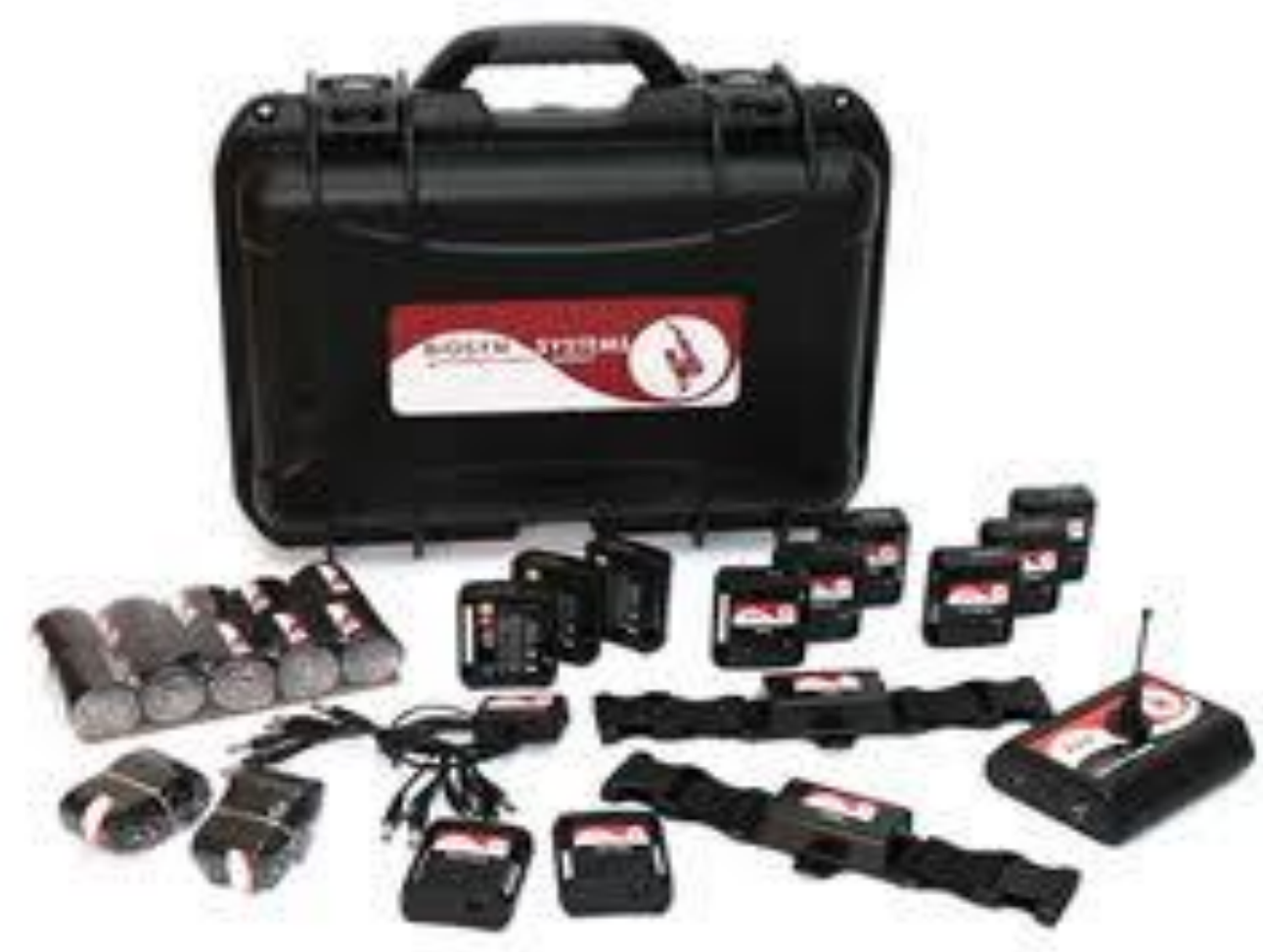

Figure 3.2 Functional assessments of biomechanics (FAB) system

\subsubsection{VDU Workstation}

Standard VDU workstation furniture, which includes an adjustable pneumatic chair, a standard office desk, and a document holder, was used. VDU screen monitor/s placed on the desk at a floor-to-tabletop distance of $70 \mathrm{~cm}$ and a chair with height adjustment range of 42 to 50 cm was used.

\subsection{Experimental tasks}

Participants performed following three tasks using single and dual screen monitor layouts (figure 3.3):

(1) reading for ten minutes

(2) typing for five minutes

(3) search and find tasks for ten minutes. 
For the reading task, participants read an article for ten minutes. During the typing task, participants typed a document while reading it from a document holder. Search and find tasks required the participants to go to a certain directory on the computer hard drive and find out information by opening a certain file in that directory. Once the information was located, participants were required to report that information by typing it in a master file. Once the information was typed in the master file, next search and find task were displayed to the participant in the master file.

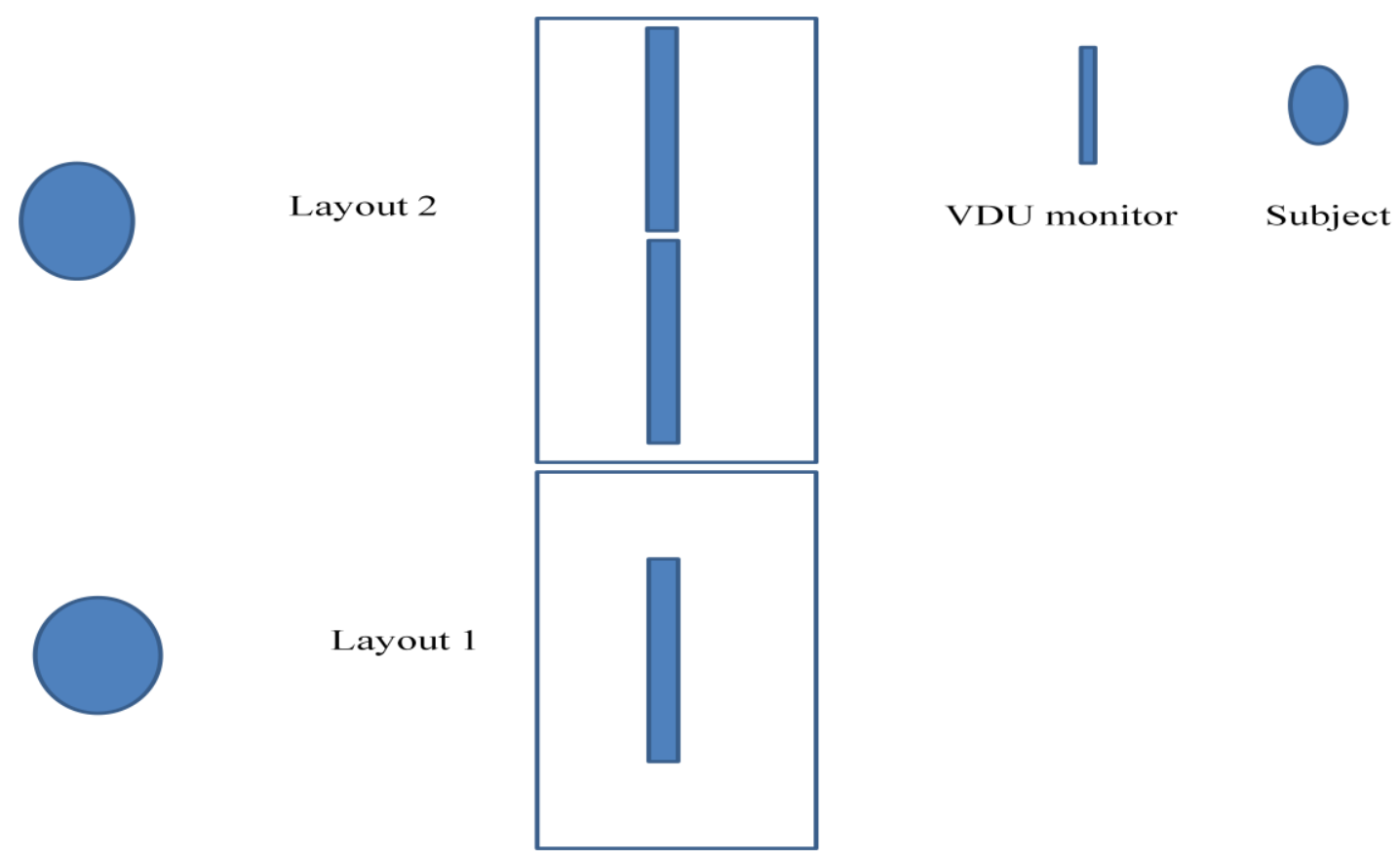

Figure 3.3 Top views of the two monitor screen layouts. Layout 1 is a single screen monitor layout. Layouts 2 is the dual screen monitor layout

\subsection{Experimental design}

A two factor factorial experimental design was used. Factor 1, monitor layout, had two fixed levels (single and dual) and factor 2, type of tasks, had three fixed levels (reading, typing, and search and find). 


\subsection{Hypothesis}

Following hypotheses were tested in this study:

$\mathrm{H}_{01}$ : main effect of "monitor layouts" will not be significant

$\mathrm{H}_{02}$ : main effect of "type of tasks" will not be significant

$\mathrm{H}_{03}$ : interaction effect will not be present

\subsection{Data collection Procedure}

\subsubsection{Anthropometric measurement}

A set of anthropometric measurements, height, weight, upper arm length, fore arm length and trunk length, shoulder width, neck length, were recorded for each participant. Some of these measurements were required as an input to the $\mathrm{FAB}$ software, while other measurements were used for determining the exact location of EMG electrodes in the neck and shoulder area. FAB software requires the basic anthropometry data to form the real-time humanoid during data collection and to precisely compute 3D kinematics between the biomechanical bodies.

\subsubsection{Data collection preparation}

Participants were fitted with the following three FAB sensors using elastic bands:

1) pelvis sensor was mounted at the approximate L5S1 level

2) trunk sensor was mounted at approximate T10-11 level

3) head sensor was mounted at about the occipital region

Subsequently, neck skin was prepped for EMG electrode placement by shaving hair (if needed) and cleaning with 70\% rubbing alcohol. EMG data was recorded from two major neckshoulder muscles: (1) sternocleidomastoid (SCM) and (2) cervical trapezius.

EMG from the sternocleidomastoid muscle was recorded by placing an electrode along a line drawn from the sternal notch to the mastoid process, at $1 / 3$ the length of the line from the 
mastoid process. Electrodes were located midway between the innervation zone and the insertion of the muscle at the mastoid process . EMG from the cervical trapezius muscle was recorded by placing an electrode at the $\mathrm{C} 4$ level, which was determined as 2.5 times the distance between the C6-C7 vertebrae above the C7 level. The electrode at this location was placed slightly inclined (approximately 35 degrees) to the vertical line between spinous processes of the $\mathrm{C} 7$ and $\mathrm{C} 4$ (Nimbarte et al., 2010). TThe EMG data was collected bilaterally.

The sternocleidomastoid muscle electrode location was tested by a measurable EMG signal during head rotation (Vasavada et al., 1998). The cervical trapezius muscle electrode location was tested by a measurable EMG signal during flexion-extension of the head (Nimbarte, 2009).

Participant then started working on the VDU to get familiarized with the workstation set up. They were instructed to adjust their chair heights to achieve a comfortable sitting posture. Comfortable sitting position was defined based on the previously published guidelines (Saito et al., 1997; Szeto and Lee, 2002): back straight, hip joint flexed 90 degrees and knee joint flexed 60 to 90 degrees (depending on the personal preference), shoulder joint in anatomically neutral posture and elbow joint flexed 60 to 90 degrees and forearm supported by adjustable arm rest. A foot rest was provided based on the personal preference. The location of the document reader was kept constant, which was lateral to the left monitor. Reading/viewing distance was set to 58 $\mathrm{cm}$ for the VDU screen and the document reader. The viewing distance was measured from the top of the viewable part of the screen to the midpoint between the eyes with the participant in a relaxed sitting position (Figure 3.4). 


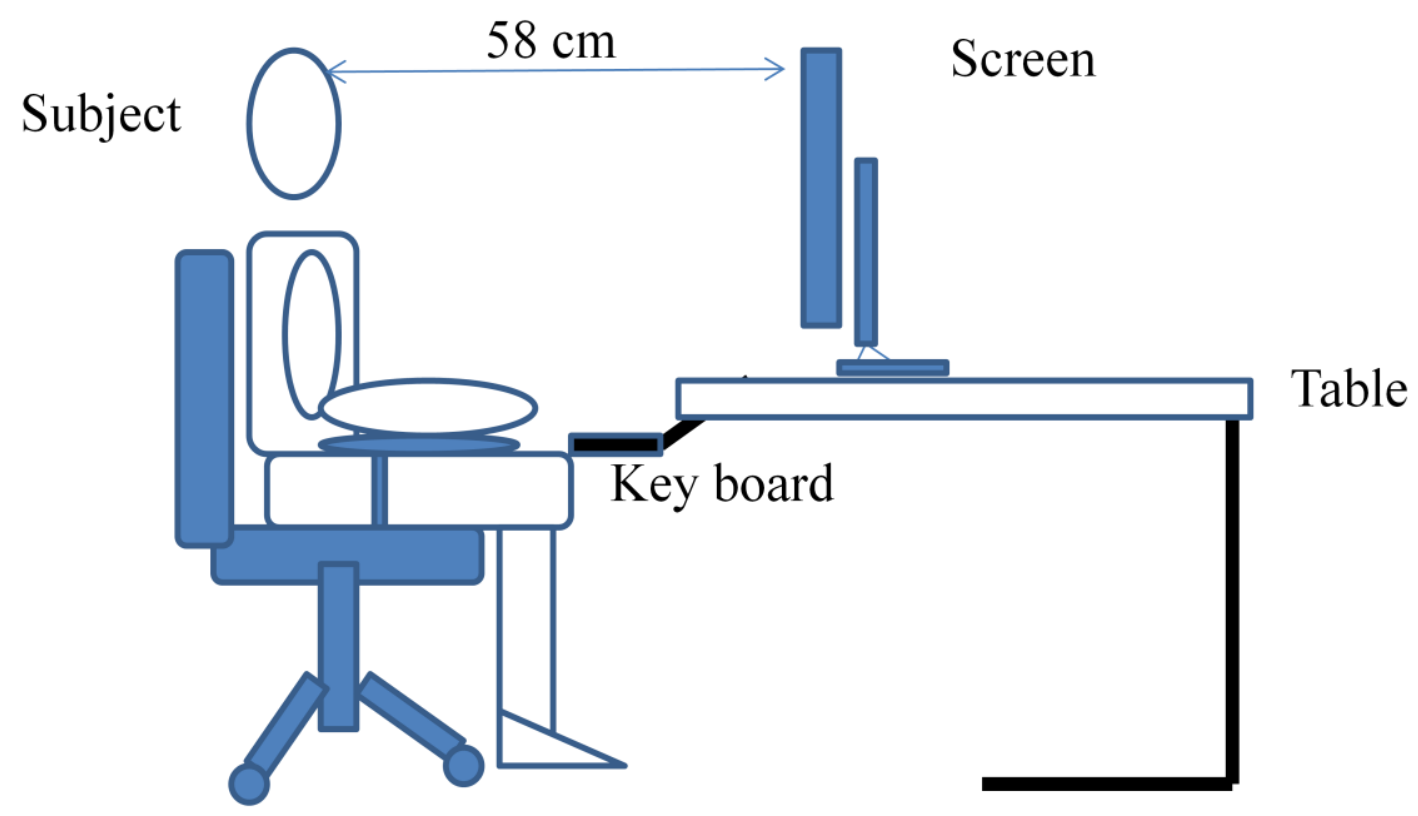

\section{Adjustable chair}

Figure 3.4 Experimental workstation

\subsection{Actual data collection}

Once the workstation parameters were set up, before the data collection trials, participants were asked to browse on the internet for five minutes to get familiarize with the set up. Participants then performed the standardized VDU tasks comprised of (reading, typing, and performing search and find tasks) for a total duration of 25 minutes. EMG and 3D motion data were recorded continuously during the three types of VDU activities.

\subsection{Data Processing and Analysis}

\subsubsection{Head-shoulder posture}

The kinematic data was processed to evaluate the postural load on the cervical spine. Postural load in this study was defined as a measure of combination of the deviation of the head from the anatomical neutral position and the amount of time user work in that non-neutral 
posture. To quantify the postural load, each kinematic trajectory, flexion, bending and rotation, was divided into segments of 5 degrees of joint rotation (e.g. 0 to 5,5 to $10, \ldots, 40$ to 45 ) and the corresponding durations in terms of percent of time were calculated. The percent time was then multiplied by the loading scores. Table 3.1 represents the loading scores used for the different joint rotation segments. Thus, for each kinematic trajectory, separate postural loads were quantified. A computer program used for performing this analysis can be found in Appendix B. The equation used for calculating postural load is as follows and:

$$
P L_{x}=\sum_{i=1}^{9} i \times\left(T_{x}\right)_{i}
$$

Where, $P L_{x} \quad$ is the postural load, where $x=$ flexion, bending, rotation $i \quad$ is the loading scores for the different joint rotation segments (Table 3.1) $T x \quad$ is the percent time for the joint rotation segments (Table 3.1)

Table 3.1 Loading scores used for the quantifying the posture load index.

\begin{tabular}{|c|c|}
\hline Joint rotation segment & $\begin{array}{c}\text { Loading scores } \\
(\mathbf{i})\end{array}$ \\
\hline $0-5$ & 1 \\
\hline $5-10$ & 2 \\
\hline $10-15$ & 3 \\
\hline $15-20$ & 4 \\
\hline $20-25$ & 5 \\
\hline $25-30$ & 6 \\
\hline $30-35$ & 7 \\
\hline $35-40$ & 8 \\
\hline $40-45$ & 9 \\
\hline
\end{tabular}




\subsubsection{Electromyography}

EMG data was processed to calculate mean absolute values (MAV). The raw EMG signal from each electrode location was demeaned and full-wave rectified. The full wave rectified EMG signal was low pass filtered at $4 \mathrm{~Hz}$, using a fourth-order dual pass Butterworth digital filter, to form a linear envelope (Burnett et al., 2007). The resulting data was averaged to determine the mean absolute values (MAV) (Acierno et al., 1995). Comparison of EMG between and within subjects involves normalizing the EMG data. Typically, EMG can be normalized with respect to 1) muscle activation at the maximum voluntary contraction; 2) reference muscle contraction while performing a standardized task (Mathiassen and Winkel, 1990; Turville et al., 1998a) and; 3) the peak or mean activation during the tasks (Finsen, 1999; Sommerich et al., 2001a). In this study, EMG was normalized with respect to the reference contraction as explained by Nimbarte et al., (2010) to determine the Normalized MAV (N-MAV).

\subsection{Statistical Analysis}

The effect of monitor layouts and type of tasks on the postural load and activities of neck muscles was evaluated using the following linear model. Since the individual participants are different in their skills and abilities to use the VDU workstation, participants were treated as blocks.

$$
y D_{i j l}=\mu+\alpha_{i}+\beta_{j}+(\alpha \beta)_{i j}+\gamma_{l}+\epsilon_{i j l}\left\{\begin{array}{c}
i=1,2 \\
j=1,2,3 \\
l=1, \ldots, 9
\end{array}\right.
$$

Where, 
$y D$ represents dependent variables. Seven dependent variables were evaluated in this study: (1)

flexion score; (2) bending score; (3) rotation score; (4) NMAV of right sternocleidomastoid; (5) NMAV of left sternocleidomastoid; (6) NMAV of right cervical trapezius; (7) NMAV of left cervical trapezius;

$\mu$ is the overall mean to all treatments.

$\alpha_{i}$ is the effect of monitor layouts. Two levels of this factors represent single and dual monitor layout, therefore $i=1,2$.

$\beta_{j}$ is the effect of type of tasks. Three levels of this factors represent reading, typing and search and find, therefore $j=1,2,3$.

$\gamma_{l}$ is the effect of subjects (block effect), $l=1,2,3,4,5,6,7,8,9$

$(\alpha \beta)_{i j}$ is the interaction effect between monitor layout and type of task.

$\epsilon_{i j l}$ is a random error term.

Monitor layout $\left(\alpha_{i}\right)$, type of task $\left(\beta_{j}\right)$ are treated as fixed factors. It is assumed that each factor and the two-way interaction factor have no effect on the dependent variables i.e.

$$
\sum_{i=1}^{2} \propto_{i}=0, \sum_{j=1}^{3} \beta_{j}=0, \sum_{i=1}^{2} \sum_{j=1}^{3}(\alpha \beta)_{i j}=0
$$

Subjects $\left(\gamma_{l}\right)$ are treated as a random factor and it is assumed that it is NID $\left(0, \sigma_{\gamma}{ }^{2}\right)$ random variable. Random error and $\epsilon_{i j l}$ follows NID $\left(0, \sigma^{2}\right)$. In this study, the Type I error $\alpha=0.05$ and Power of the test $(1-\beta)=0.90$ were chosen for the hypothesis test. The power analysis for the sample size of nine is explained in the following section.

\subsubsection{Power Analysis}

Operating characteristics curves (OC curves), a graph of $\beta$ (type II error probability) versus the true difference in means, was used for performing the power analysis for the sample 
size of nine used in this study. The random factor subject $\left(\gamma_{k}\right)$ is treated as a block, so here the number of subjects is same as the number of blocks. Based on the above statistical model, the OC curves are used with the equation:

$$
\lambda=\sqrt{1+\frac{c \sigma_{\gamma}^{2}}{\sigma^{2}}}
$$

Where,

$\sigma_{\gamma}^{2}=M S B L$, Mean square of blocks

$\sigma^{2}=M S E$, Mean square error

$\mathrm{c}=$ number of subjects

Based on the data collected from nine subjects $(\mathrm{c}=9), M S B L$ and $M S E$ were calculated. For nine subjects $(c=9)$, from the OC curve, it was found that $\beta$ was less than 0.03 for all the dependent variables. Therefore, the power of the test was approximately $(1-\beta)=1-0.03=0.97$, which is more than the pre-selected power of at least 0.90 . 


\section{Chapter 4: Result}

Participants in this study were in the age group of 22 to 35 years and had more than 5 years of experience with the single monitor VDU. All the participants were males. Average height and weight of the participants were 167.5(4.14) and 69.8(6.7), respectively. On an average, participants used VDU for more than $82 \%$ of the time per week at work. None of the participants were professional typist and most of them used 5 to 6 fingers for typing.

\subsection{Posture}

ANOVA tables for the postural load caused by the cervical flexion, bending and rotation are shown in the Table 4.1. The raw postural load data can be found in appendix D. Type of task significantly affected the postural load caused by cervical flexion and bending $(\mathrm{P}<0.000)$. Results of Tukey HSD All-pairwise comparison test showed that the mean of the postural load caused by the cervical flexion and bending during typing task was different than the corresponding reading, and, search and find tasks (Table 4.1, Figure 4.1 (A)). The overall cervical spine flexion and bending postures, expressed in terms of average of the percent time of different joint angles are shown in figure 4.2. During typing tasks, around neutral postures (0 to 10 degrees of flexion) were adopted for least amount of time and users worked in flexed head postures, between 10 to 20 degrees, for over $45 \%$ of the time. The average of the percent time, when more flexed postures were used (20 to 30 degrees, $>20$ degrees), was also higher during typing task than search and find, and reading task. A relatively stable and around neutral cervical bending postures were used by the users during the search and find and reading tasks. During the typing task, some increase in the cervical bending was observed. It was found that on an average, for $15 \%$ of the time users worked in postures, with cervical bending between 10 to 20 degrees. The effect of monitor layout on the postural load caused by the cervical flexion and bending was 
statistically insignificant. However, a general trend showed that dual screen monitor layout was associated with somewhat higher postural loads.

Table 4.1 ANOVA table for postural load by the cervical flexion, bending and rotation.

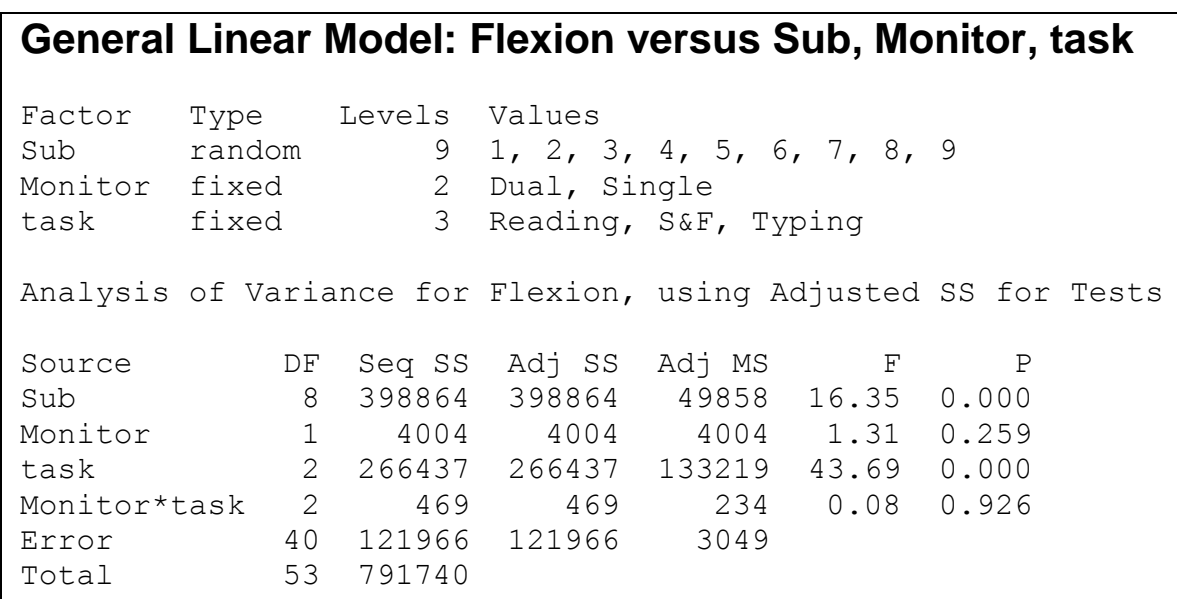

\section{General Linear Model: Bending versus Sub, Monitor, task}

\begin{tabular}{|c|c|c|c|c|c|c|c|c|}
\hline Factor & Type & & Levels & Values & & & & \\
\hline Sub & rand & & 9 & $1,2,3$, & 5,6 & 7,8, & 9 & \\
\hline Monitor & fixe & & 2 & Dual, Sing & le & & & \\
\hline task & fixe & & 3 & Reading, & $\& \mathrm{~F}, \quad$ Typ & $n g$ & & \\
\hline Analysis & of $V$ & $\operatorname{aric}$ & nce for & Bending, & Asing $\mathrm{Ad}$ & usted & SS for & Tests \\
\hline Source & & $\mathrm{DF}$ & Seq SS & Adj $S S$ & Adj MS & $\mathrm{F}$ & P & \\
\hline Sub & & 8 & 26010.7 & 26010.7 & 3251.3 & 3.57 & 0.003 & \\
\hline Monitor & & 1 & 2241.0 & 2241.0 & 2241.0 & 2.46 & 0.125 & \\
\hline task & & 2 & 8464.6 & 8464.6 & 4232.3 & 4.64 & 0.015 & \\
\hline Monitor*to & rask & 2 & 1169.8 & 1169.8 & 584.9 & 0.64 & 0.532 & \\
\hline Error & & 40 & 36475.1 & 36475.1 & 911.9 & & & \\
\hline Total & & 53 & 74361.1 & & & & & \\
\hline
\end{tabular}

\section{General Linear Model: Rotation versus Sub, Monitor, task}

\begin{tabular}{|c|c|c|c|c|c|c|c|c|}
\hline $\begin{array}{l}\text { Factor } \\
\text { Sub } \\
\text { Monitor } \\
\text { task }\end{array}$ & $\begin{array}{l}\text { Typ } \\
\text { ran } \\
\text { fix } \\
\text { fix }\end{array}$ & & $\begin{array}{r}\text { Levels } \\
9 \\
2 \\
3\end{array}$ & $\begin{array}{l}\text { Values } \\
1,2,3, \\
\text { Dual, Sin } \\
\text { Reading, }\end{array}$ & $\begin{array}{l}4,5, \\
\text { gle } \\
S \& F, T\end{array}$ & $\begin{array}{l}\text {, } 7,8, \\
\text { ping }\end{array}$ & & \\
\hline Analysis & of & $\operatorname{aric}$ & ance for & Rotation, & using & Adjusted & SS fol & or \\
\hline Source & & $\mathrm{DF}$ & Seq SS & Adj $S S$ & Adj MS & F & $\mathrm{P}$ & \\
\hline Sub & & 8 & 512094 & 512094 & 64012 & 17.31 & 0.000 & \\
\hline Monitor & & 1 & 113044 & 113044 & 113044 & 30.57 & 0.000 & \\
\hline task & & 2 & 78572 & 78572 & 39286 & 10.62 & 0.000 & \\
\hline Monitor*t & zask & 2 & 32098 & 32098 & 16049 & 4.34 & 0.020 & \\
\hline Error & & 40 & 147915 & 147915 & 3698 & & & \\
\hline Total & & 53 & 883723 & & & & & \\
\hline
\end{tabular}



(A) PL-Flexion
- Dual
- Single

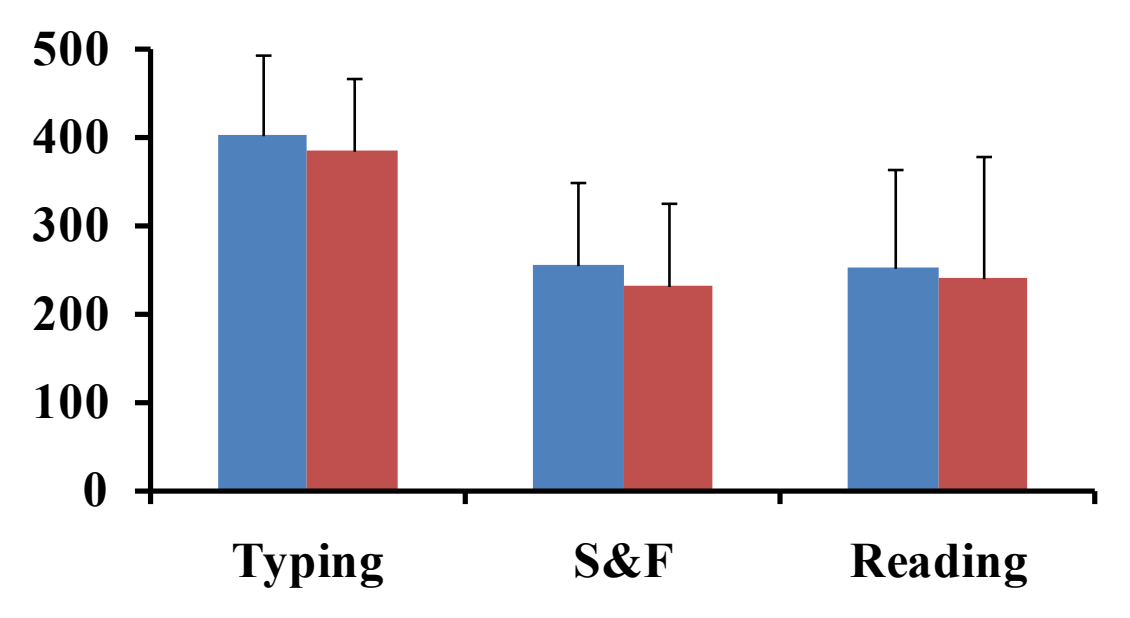

(B) PL-Bending

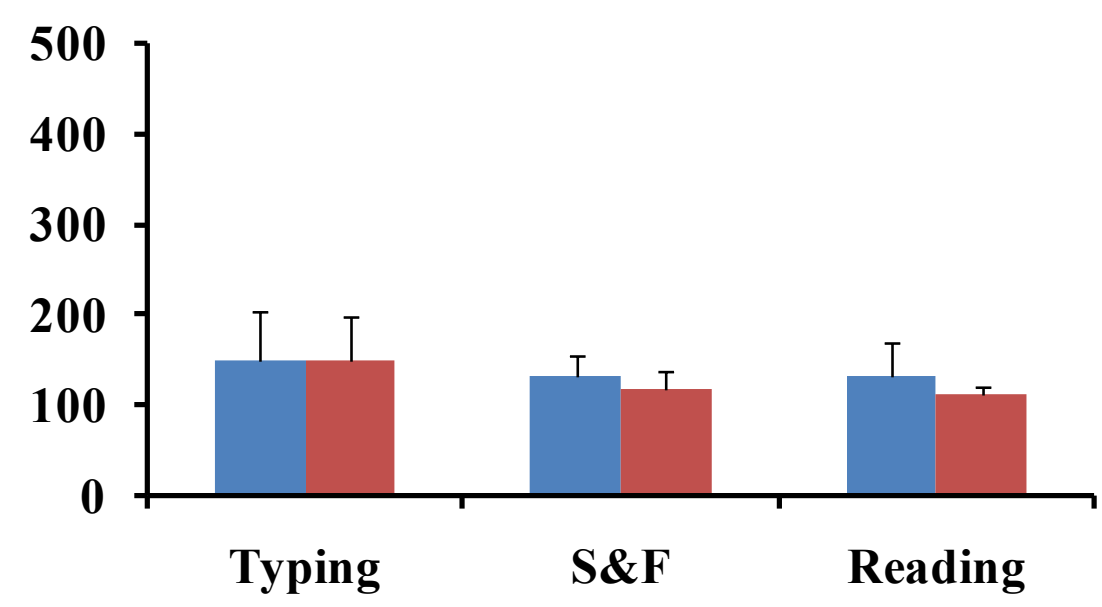

(C) PL-Rotation

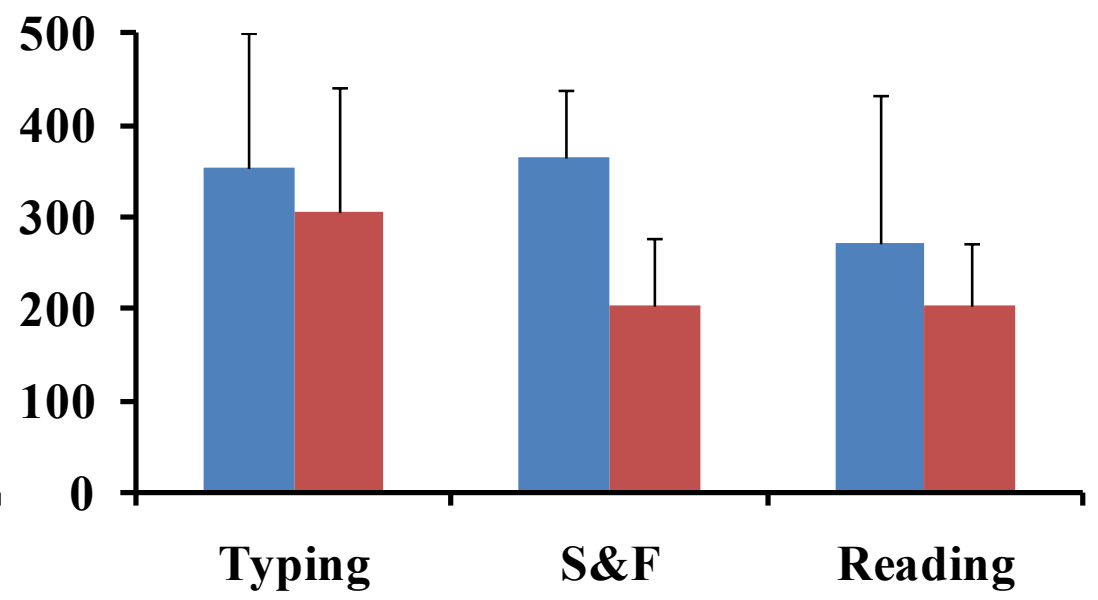

Figure 4.1 Overall postural load by (A) cervical flexion; (B) cervical bending; (C) cervical rotation as a function of type of tasks and monitor layouts. 
Table 4.2: Mean (SD) of the postural load by cervical flexion, bending, and rotation

\begin{tabular}{|c|c|c|c|c|}
\hline \multicolumn{2}{|c|}{} & Flexion & Bending & Rotation \\
\hline \multirow{3}{*}{ Dual } & Typing & $403.3(91.8)$ & $149.7(55.0)$ & $353.2(147.4)$ \\
\cline { 2 - 5 } & S\&F & $256.1(93.7)$ & $133.0(22.4)$ & $364.0(75.5)$ \\
\cline { 2 - 5 } & Reading & $251.7(113.6)$ & $132.7(37.4)$ & $270.1(163.6)$ \\
\hline \multirow{3}{*}{ Single } & Syping & $385.5(83.2)$ & $149.6(48.6)$ & $306.0(135.3)$ \\
\cline { 2 - 5 } & S\&F & $232.0(94.7)$ & $116.7(19.8)$ & $204.6(72.9)$ \\
\cline { 2 - 5 } & Reading & $241.9(138.3)$ & $110.5(11.2)$ & $202.2(68.6)$ \\
\hline
\end{tabular}

In case of postural load by cervical rotation, interaction effect between the type of task and monitor layout was statistically significant. In general, during all the tasks, dual screen monitor layout caused increase in the postural load. The results of Tukey HSD All-pairwise comparison test showed that, mean of postural load during the search and find task for dual screen monitor layout was different than single screen monitor layout (Table 4.1). On an average, use of dual screen monitor increased the postural load during typing, search and find, and reading tasks by $15 \%, 78 \%$, and $34 \%$, respectively. The primary reason of this increased postural load during the search and find task was that participants were working in non-neutral, more rotated head postures, for comparatively higher duration of time. Figure 4.3 shows averages of the percent of time spent by the users at different degrees of cervical rotation during single and dual monitor use. The overall trend indicates that, single monitor layout was primarily associated with more symmetrical working postures. These postures were characterized by 
higher durations of lower degrees of cervical rotation (0 to 10 degrees). However, dual monitor layout was associated with asymmetrical (more rotated) head postures, characterized by higher durations of higher degrees of cervical rotation (20 to 30 degrees). This trend was quite apparent during search and find, and reading tasks.
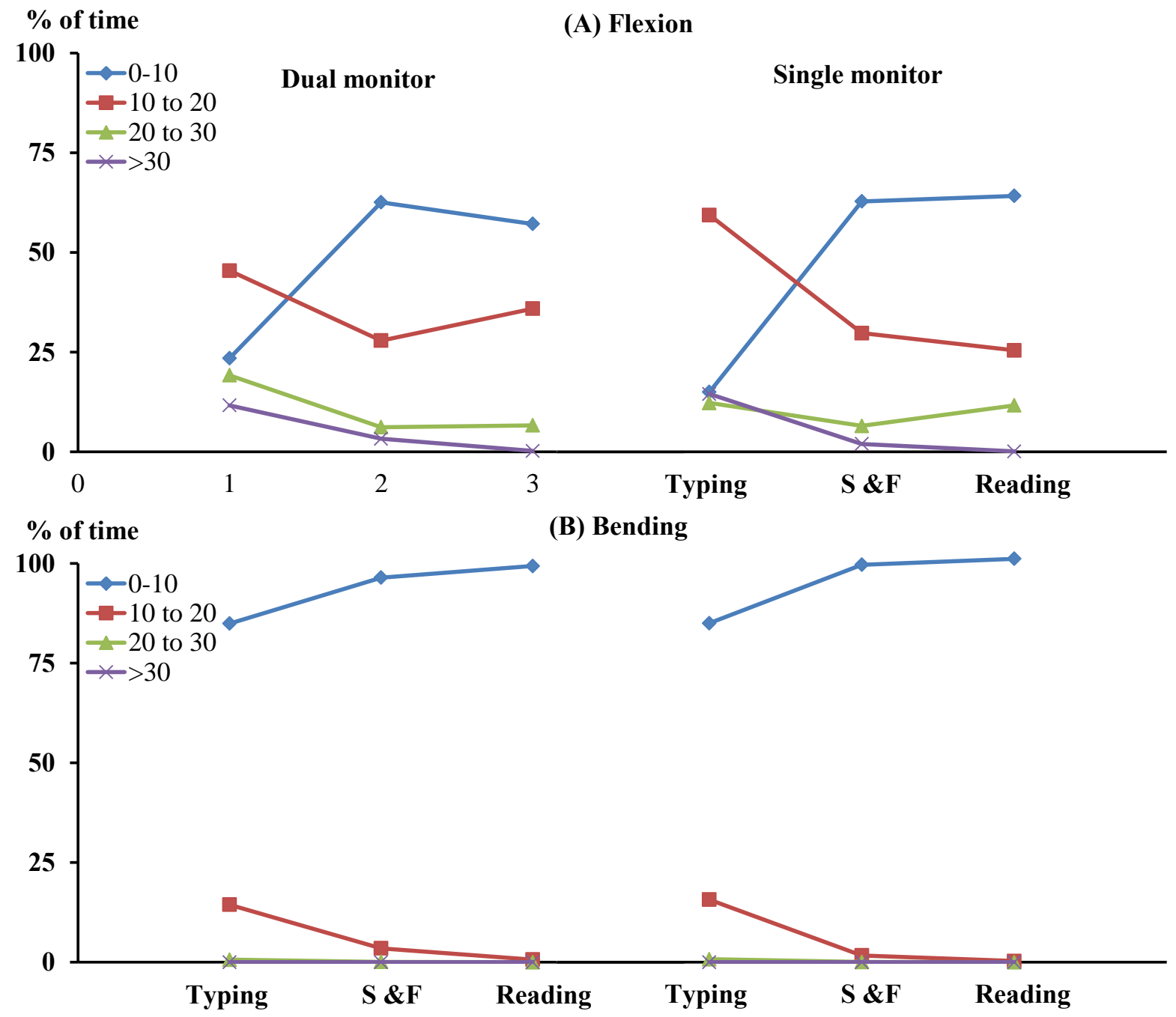

Figure 4.2: Flexion and bending postures during the typing, search and find, and reading tasks 

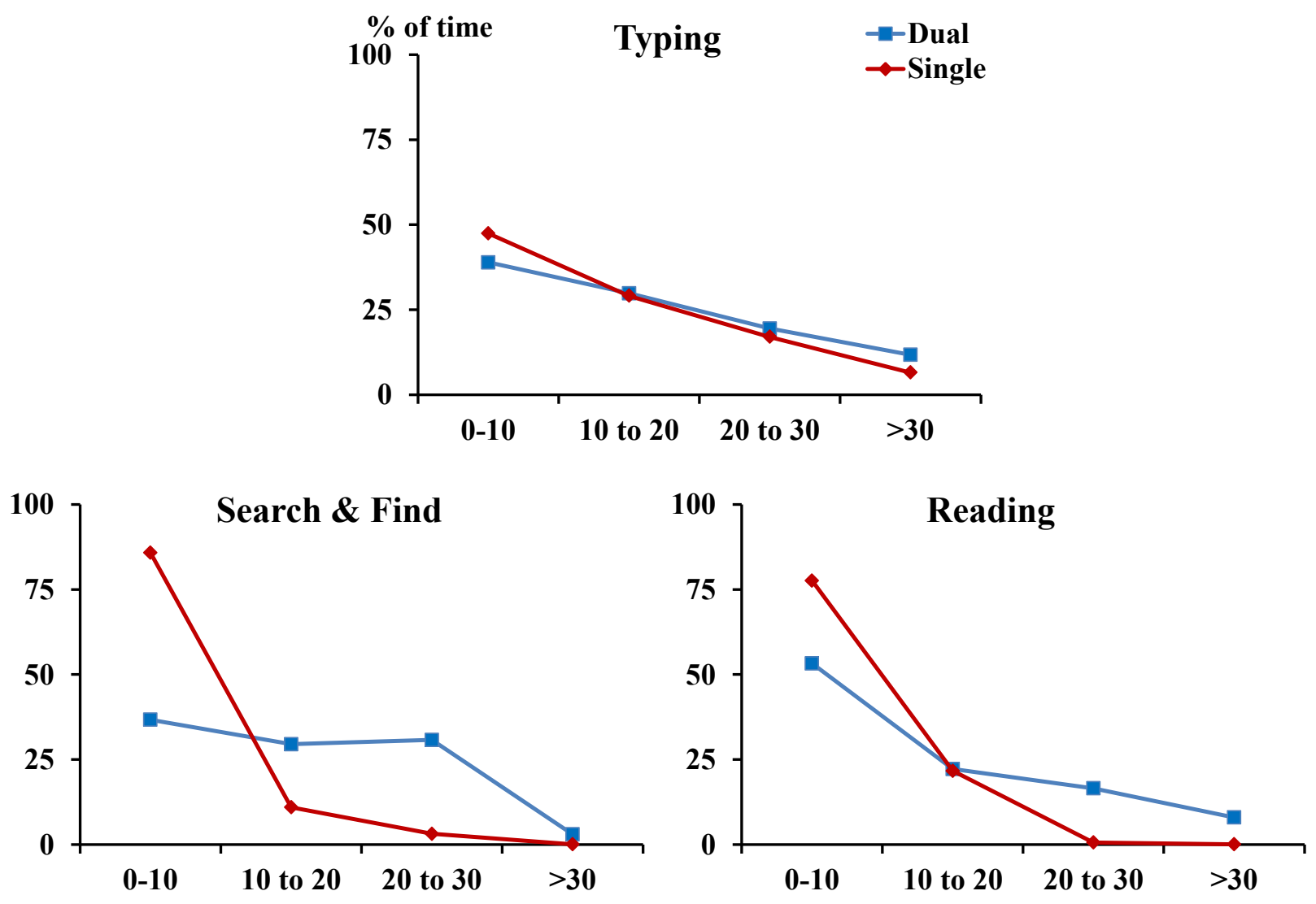

Figure 4.3: Cervical rotation during typing, search and find, and reading tasks

The adequacy of general linear model used for studying postural load by cervical flexion, bending, and rotation was evaluated by using normal probability plot of residuals. This plot was almost a straight line for the postural loads by flexion, bending and rotation, indicating that error distribution is approximately normal (Appendix C).

\subsection{Muscle Activity}

ANOVA tables for the electromyographic activities of the anterior neck muscle, sternocleidomastoid, are shown in Table 4.3. The raw muscle activity data can be found in appendix E. For the sternocleidomastoid muscle on the right side, main effects of the type of task and monitor layout was statistically significant $(\mathrm{P}<0.000)$. Results of Tukey HSD All-pairwise 
comparison test show that mean of activation level of this muscle when working with dual screen monitors was different than single screen monitor (Figure 4.4). Between tasks comparison shows highest mean activation level for this muscle during typing task, followed by search and find, and reading tasks. Results of Tukey HSD All-pairwise comparison test show that during typing task mean of muscle activation was different than the other two tasks (Table 4.4).

Table 4.3 ANOVA table for N-MAV of the sternocleidomastoid muscles

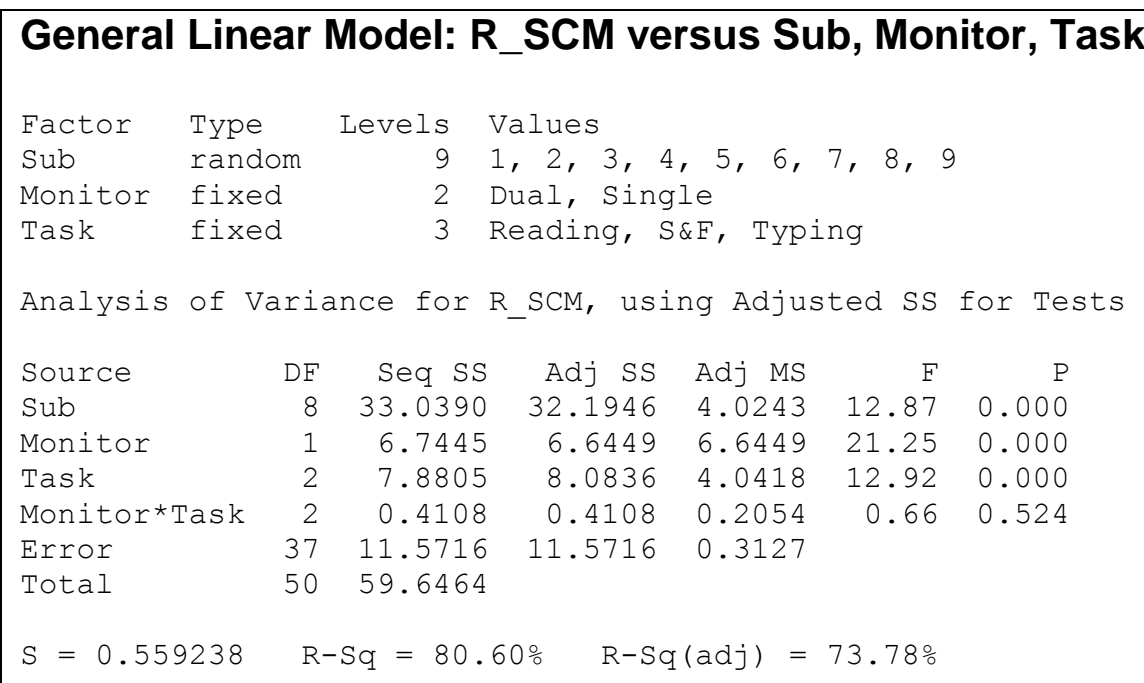

\section{General Linear Model: L_SCM versus Sub, Monitor, Task}

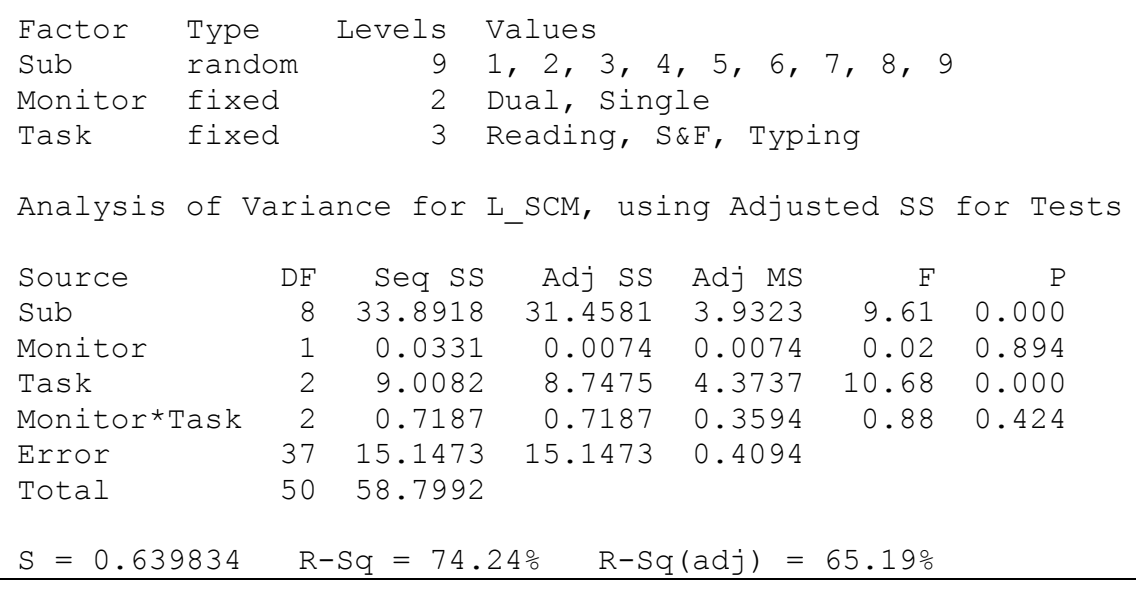



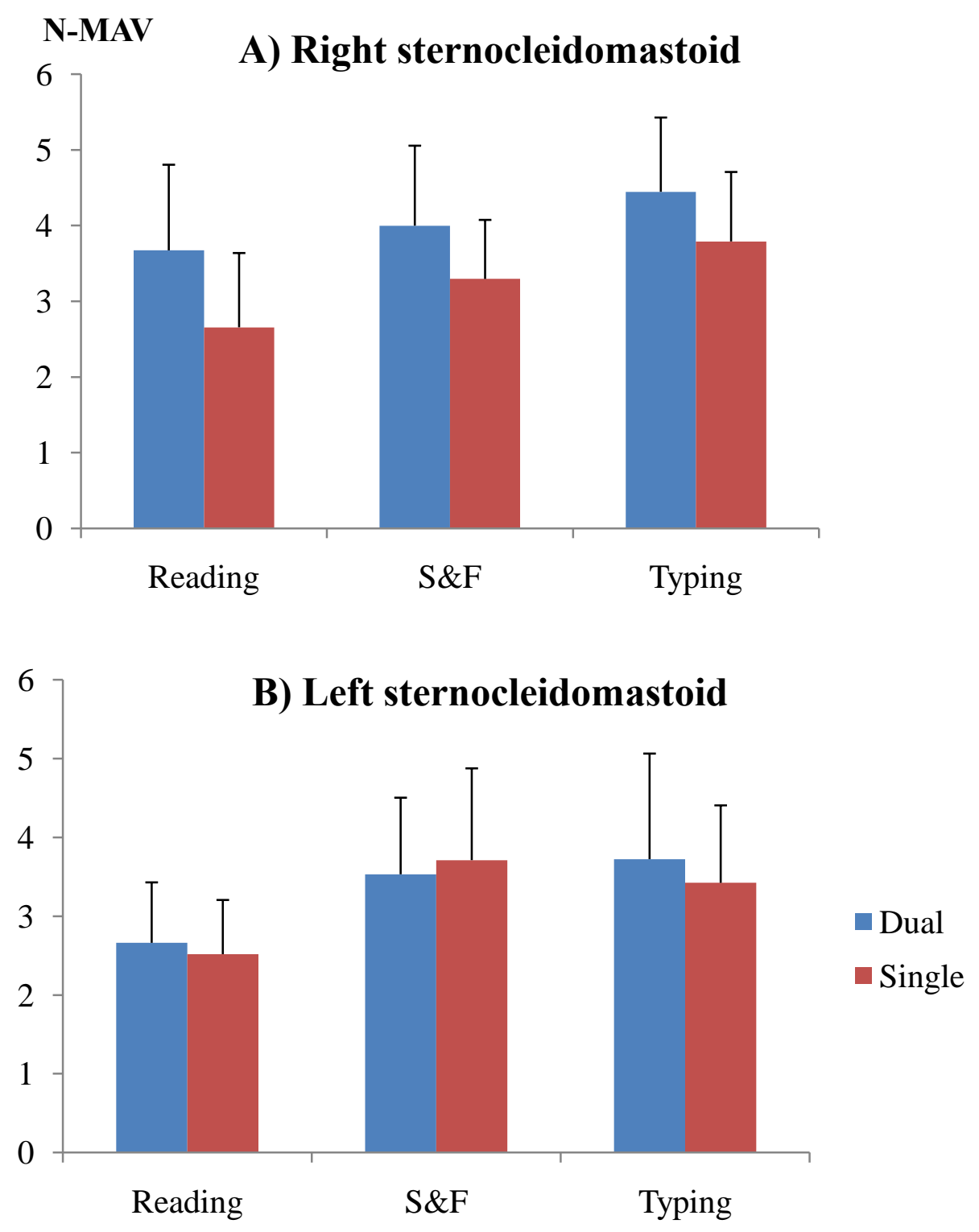

Figure 4.4: Normalized muscle activity of the sternocleidomastoid muscles

The activation level of sternocleidomastoid muscle on the left side was significantly affected by the type of task $(\mathrm{P}<0.000)$. This muscle worked to almost a same intensity during search and find and typing tasks. Results of Tukey HSD All-pairwise comparison test show that mean muscle activation during reading task was different (lower) than the search and find and typing tasks. No consistent trend in the behavior of this muscle with respect to the monitor layout 
was observed (Figure 4.4, Table 4.4). The main effect of monitor layout on the activation level of sternocleidomastoid muscle on the left side was statistically insignificant.

Table 4.4: Mean (SD) of the normalized muscle activity during the reading, search and find, and typing tasks

\begin{tabular}{|c|c|c|c|c|c|}
\hline & & \multicolumn{2}{|c|}{ Dual } & \multicolumn{2}{|c|}{ Single } \\
\hline & & Mean & SD & Mean & SD \\
\hline \multirow{4}{*}{ Reading } & Sternocleidomastoid Right & 3.67 & 1.13 & 2.66 & 0.78 \\
\hline & Sternocleidomastoid Left & 2.66 & 0.77 & 2.52 & 0.69 \\
\hline & Cervical trapezius right & 2.49 & 0.85 & 2.78 & 1.19 \\
\hline & Cervical trapezius left & 4.33 & 0.96 & 4.94 & 1.03 \\
\hline \multirow{5}{*}{$\begin{array}{l}\text { Search \& } \\
\text { Find }\end{array}$} & & & & & \\
\hline & Sternocleidomastoid Right & 4.00 & 1.06 & 3.29 & 0.92 \\
\hline & Sternocleidomastoid Left & 3.53 & 0.97 & 3.71 & 1.16 \\
\hline & Cervical trapezius Right & 3.78 & 1.25 & 3.60 & 0.94 \\
\hline & Cervical trapezius Left & 5.47 & 1.83 & 6.16 & 1.41 \\
\hline \multirow{4}{*}{ Typing } & Sternocleidomastoid Right & 4.45 & 0.98 & 3.79 & 1.00 \\
\hline & Sternocleidomastoid Left & 3.72 & 1.34 & 3.42 & 0.98 \\
\hline & Cervical trapezius Right & 5.05 & 1.70 & 3.95 & 1.59 \\
\hline & Cervical trapezius Left & 7.01 & 1.99 & 6.47 & 1.72 \\
\hline
\end{tabular}

Table 4.5 ANOVA table for N-MAV of the cervical trapezius muscles

$$
\begin{aligned}
& \text { General Linear Model: R_TRP Upper versus Sub, Monitor, Task } \\
& \begin{array}{llrl}
\text { Factor } & \text { Type } & \text { Levels } & \text { Values } \\
\text { Sub } & \text { random } & 9 & 1,2,3,4,5,6,7,8,9
\end{array} \\
& \text { Monitor fixed } 2 \text { Dual, Single } \\
& \text { Task fixed } 3 \text { Reading, S\&F, Typing } \\
& \text { Analysis of Variance for R_TRP Upper, using Adjusted SS for Tests } \\
& \text { Source DF Seq SS Adj SS Adj MS } \quad \text { F } \quad P \\
& \begin{array}{lllllll}
\text { Sub } & 8 & 56.0765 & 58.9182 & 7.3648 & 17.32 & 0.000
\end{array}
\end{aligned}
$$

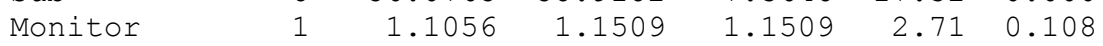

$$
\begin{aligned}
& \begin{array}{lllllll}
\text { Task } & 2 & 35.7733 & 34.2895 & 17.1447 & 40.32 & 0.000
\end{array}
\end{aligned}
$$

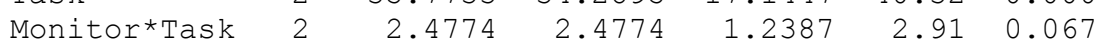

$$
\begin{aligned}
& \text { Error } \quad 37 \quad 15.7335 \\
& \text { Total } 50 \quad 111.1664 \\
& S=0.652097 \quad R-S q=85.85 \% \quad R-S q(\operatorname{adj})=80.87 \%
\end{aligned}
$$

General Linear Model: L_TRP Upper versus Sub, Monitor, Task 


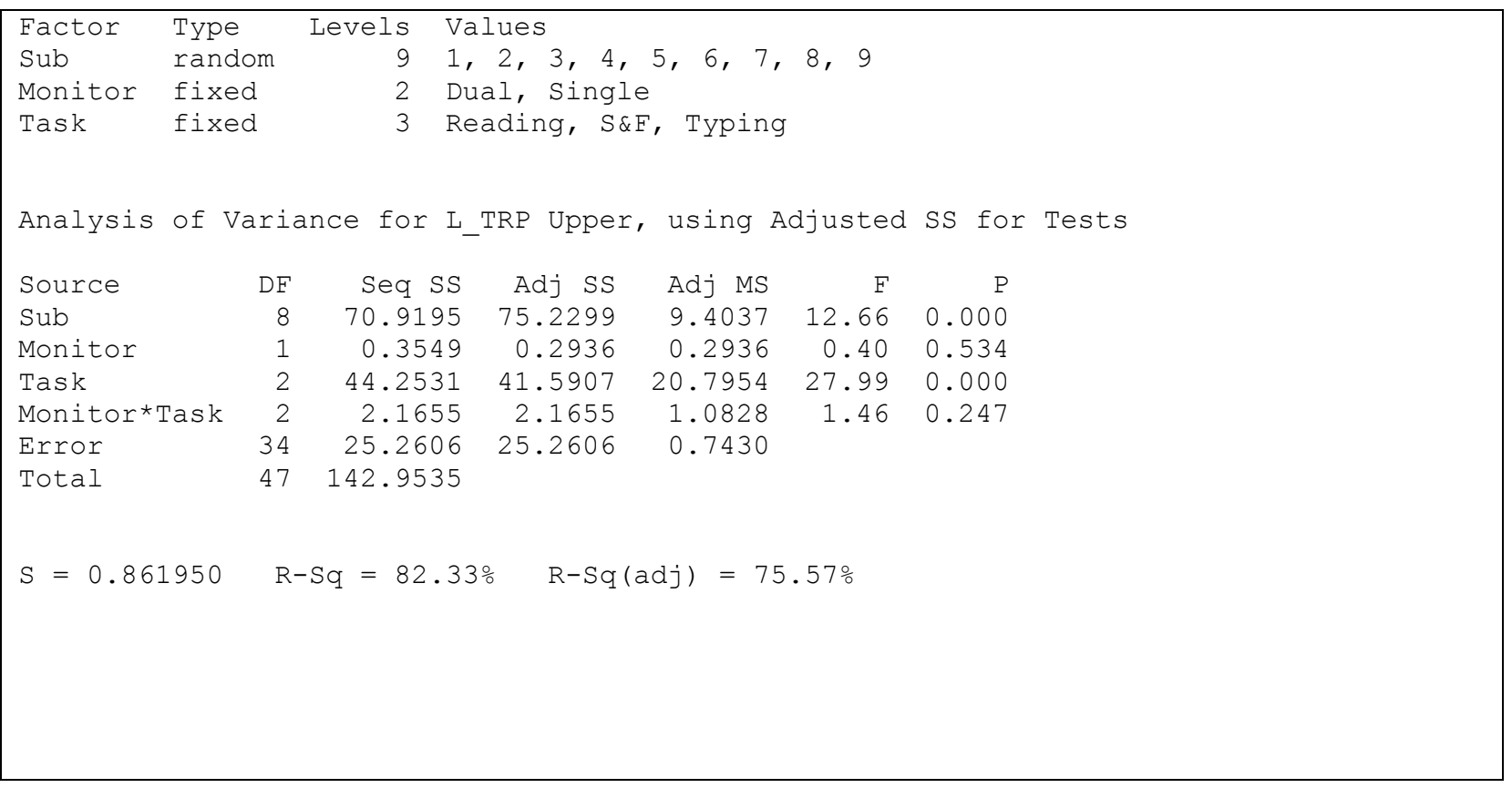

ANOVA tables for the electromyographic activities of the posterior neck muscle, cervical trapezius, are shown in Table 4.5. The activities of cervical trapezius muscle on right side were significantly affected by the type of task. The trend in the mean activation level indicate that this muscle worked the most during typing task, followed by search and find, and reading tasks.

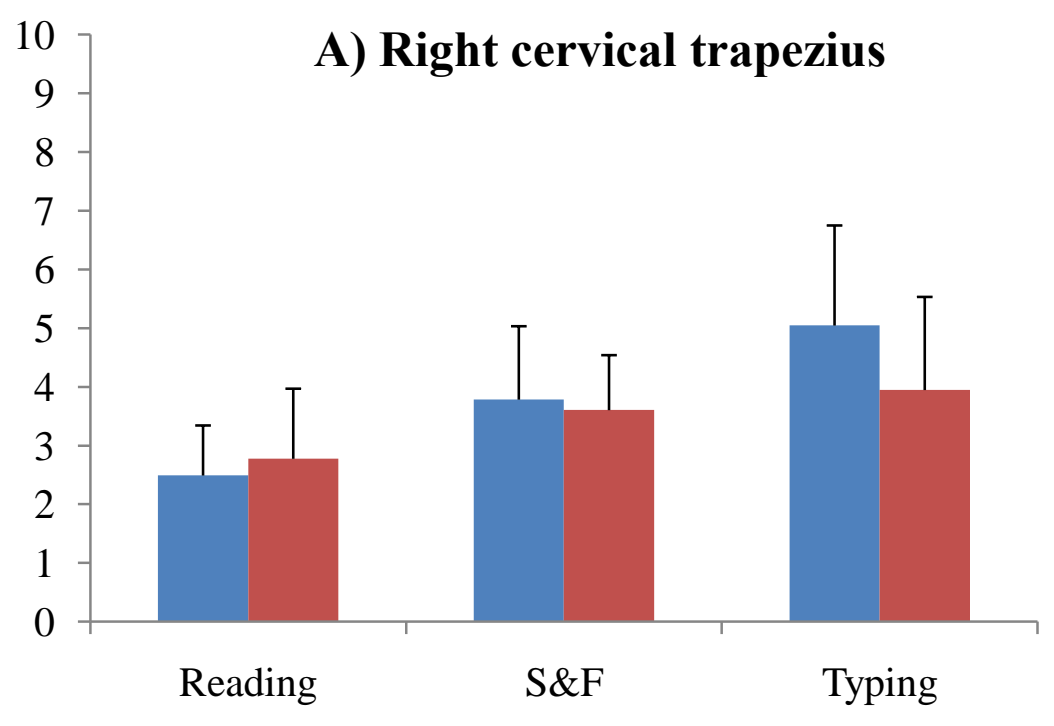




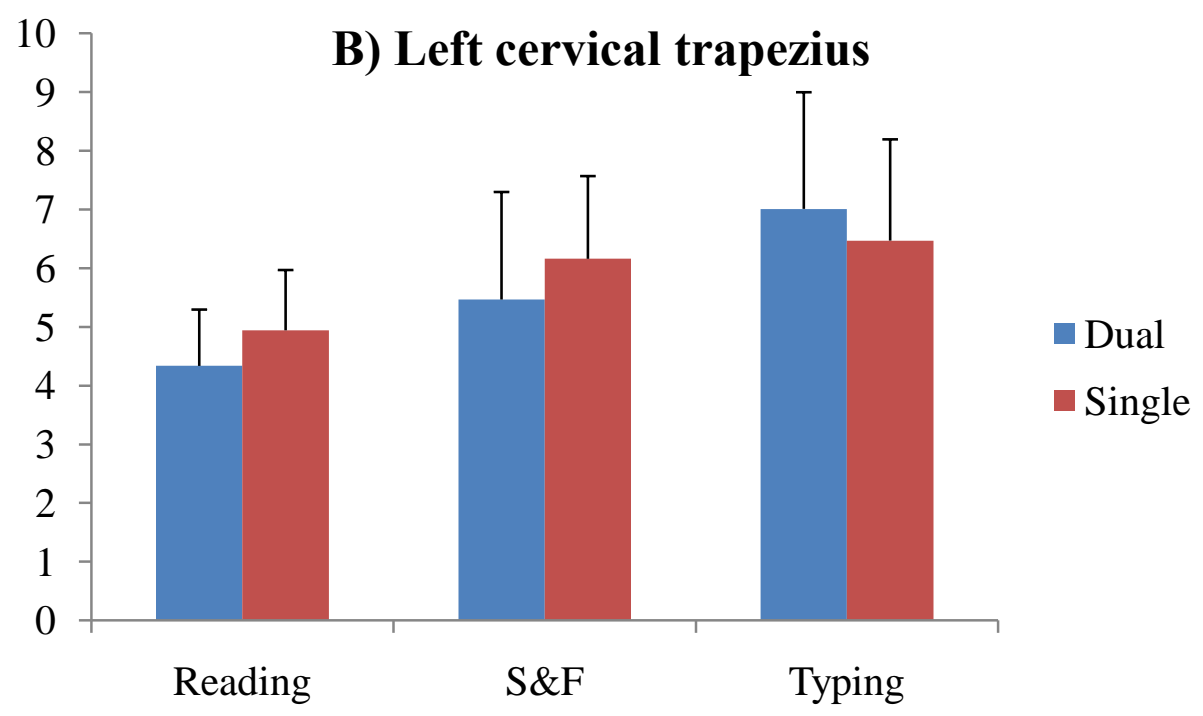

Figure 4.5 Normalized activity of the cervical trapezius muscles

Results of Tukey HSD All-pairwise comparison test show that mean of muscle activation during the three tasks were significantly different from one another (Figure 4.5, Table 4.4). The mean and standard deviation for cervical muscle shown is shown in Appendix C. The effect of monitor layout on the activation level of cervical trapezius muscle on the right side was statistically insignificant. A general trend in the mean activation level indicate that during typing task this muscle worked harder when using dual monitor layout than single monitor layout. During search and find and reading tasks, a slight difference in the muscle activation level between two types of layout was observed.

Figure 4.5 shows the behavior of the cervical trapezius muscle on left side as a function of type of tasks and monitor layout. The overall behavior of the cervical trapezius muscle on left side with respect to the type of tasks was same as the right side. Among the three tasks, this muscle worked the hardest during typing task, followed by search and find, and reading tasks. Results of Tukey HSD All-pairwise comparison test show that means of muscle activation during the three tasks were significantly different from one another (Table 4.4). The effect of 
monitor layout on the activation level of this muscle was statistically insignificant. During typing task this muscle showed slightly higher activities during dual monitor use and during reading and search and find tasks muscle activation level during single monitor use was slightly higher than dual monitor use.

Normal probability plots of residuals for muscle activity data are shown in Appendix B. These plots also show approximate straight lines indicating that the error distribution is approximately normal. 


\section{Chapter 5: Discussion and conclusions}

This study was aimed at comparing the effect of single screen to dual screen monitor use on 3D head neck postures and the activation level of neck muscles during common VDU operations. The working postures used while operating VDU are constrained by a number of factors such as positions of monitor, keyboard, and mouse and their relative locations with respect to the seating surface. Findings of previous studies suggest that monitor position affects the orientation of the head, where as upper extremity postures are more sensitive to the positions of keyboard and mouse. A number of previous investigations have studied the effect of different monitor height settings on the head and neck postures. Typically high, medium, and low monitor height settings below the horizontal at eye level were studied. Such monitor locations were found to affect head and neck position primarily in the sagittal (flexion-extension) plane. Addition of a second monitor increases the total desktop area that may require multidimensional head and neck motions while operating dual screen monitor VDU. Based on the analysis of 3D head and neck kinematics, results of this study show that use of dual monitor layout slightly changes the postural load caused by head neck flexion and bending, but significantly increase the postural load caused by head neck rotation. The postural load used in this study was an estimate of combination of non-neutral head neck postures and the corresponding durations. Higher postural load by rotation indicate that users, while working with dual monitor layout, adopted asymmetrical, more rotated, head and neck postures. With a single monitor layout, users adopted working postures with head and neck rotation in the range of $0^{\circ}$ to $10^{\circ}$ for over $70 \%$ of the time. Whereas in case of dual screen monitor a wide range of head and neck rotation, $0^{\circ}$ to $45^{\circ}$ degrees, was used by the users and spent on an average $27 \%, 22 \%$ and $8 \%$ of the time with their head rotated $10^{\circ}$ to $20^{\circ}, 20^{\circ}$ to $30^{\circ}$, and $>30^{\circ}$, respectively. 
In this study three types of tasks, reading, typing, and search and find, were evaluated. The working postures observed in this study during the reading task performed using a single monitor layout is comparable with the findings of Turville et al (1998b). An average head tilt of $3.1^{\circ}(\mathrm{SD}=5.76)$ was reported by Turville et al $(1998 \mathrm{~b})$ during a typing task performed over a duration of 10 minutes. The results of the current study show that users worked nearly $64 \%$ of the time with their head flexed between $0^{\circ}$ to $10^{\circ}$ degrees while performing the reading task for 10 minutes. During typing task, a more flexed head and neck postures for relatively higher durations of time were observed in this study. On an average, users adopted head neck flexion of between $0^{\circ}$ to $10^{\circ}, 10^{\circ}$ to $20^{\circ}, 20^{\circ}$ to $30^{\circ}$, and $>30^{\circ}$ degrees for $14.8 \%, 58.5 \%, 12.1 \%$, and $14.3 \%$ of the time respectively. The corresponding values during the search and find tasks were $61.9 \%, 29.4 \%, 6.43 \%, 1.9 \%$, respectively. This observed is trend to some extent similar with the findings of Babski-Reeves et al. (2005). A higher degree of postural shift in the flexion extension plane during typing than simple math task was reported by Babski-Reeves et al.(2005). The overall nature of the simple math task used in this study was similar to the search and find used in the present study.

The type of task was found to significantly affect the postural load. Among the three tasks, the highest postural load by flexion and bending was observed during typing task followed by the search and find, and reading tasks. Three motion components were associated with the typing task: (1) looking at the word document; (2) looking at the keyboard; (3) looking at the monitor. During search and find task although users looked at the keyboards at few instances while typing the target names/words, most of the time they were looking at the monitor. Whereas during the reading task, the primary motion involved was looking at the monitor. Since none of the users in this study were professional typist, they looked at the keyboard for substantial 
amount of time during typing task which required them to flex and to some extend laterally bend their head, and therefore a higher postural load by flexion and bending was observed during typing. For the postural load by rotation, a significant interaction between the type of task and monitor layout was observed. In general dual screen monitor arrangement involved higher postural load by rotation. For single screen monitor the postural load by rotation for search and find, and reading task was similar and lower compared to typing task. Whereas, for dual screen monitor, the postural load by rotation for search and find, and typing task was similar and higher compared to reading task. Higher postural load by rotation during typing task while using single screen monitor was due to the increased head neck rotation required to read source document from the document holder. In case of dual screen monitor the position of the document holder was shifted laterally of its original position. This arrangement required additional amount of head rotation to read the source document. During search and find task, head rotation was constrained by width of the monitor screen/s and therefore dual screen monitor layout involved almost similar amount of postural load by rotation as typing task. In case of reading task, rotational postures were constrained by width of only one screen and therefore the lowest postural load by rotation was observed for both the configurations. Higher postural load by rotation for dual screen monitor layout during reading task was because of the lateral shift in the position of monitors.

The present study indicates differences in the activities of head stabilizing muscles between the three types of tasks. Typing task has elicited higher activities in the cervical trapezius and sternocleidomastoid muscles, followed by the search and find, and reading task. The cervical trapezius muscle is a major posterior neck muscle that controls head movement in forward and lateral directions. The sternocleidomastoid muscle, on the other hand supports head 
weight during rotation, bending and extension. Typing task involved head movements in all the three anatomical planes (sagittal, transverse, frontal), and therefore a relatively higher contralateral muscle activity of neck muscles was observed compared to the other two tasks. A number of previous studies have reported increased activity of neck muscles, especially cervical extensor (cervical trapezius) during VDU operations performed with more flexed head postures (Babski-Reeves et al., 2005; Szeto and Sham, 2008; Turville et al., 1998b). In the present study, for single as well as dual screen monitor layout, cervical load by flexion was the highest during typing task indicating that users adopted flexed head postures for higher durations. Therefore, the observed increase in the neck muscle activity during the typing task is in agreement with the previous studies.

The results of the present study show important changes in the muscle activity patterns of right sternocleidomastoid in response to different monitor layouts. Independent of type of tasks, right sternocleidomastoid muscle showed relatively higher activity while using dual screen monitor. As noted sternocleidomastoid muscle, play important role in supporting head weight during rotation. The observed increase in the activity of right sternocleidomastoid muscle was due to the increased postural load by rotation associated with the dual screen monitor layout. Surprisingly for the muscle on the left side, no consistent trend in the activity with respect to different monitor layout was observed. Possible reason for this observation could be that participants may have adopted counterclockwise rotation more frequently, requiring this muscle to act as an antagonist. Only the absolute values of head and neck rotations were evaluated in this study. If positive and negative rotation were evaluated, it would have provided better insight into the relationship of head rotation and activity of sternocleidomastoid muscles. Furthermore, all the participants in this study were right handed and it is possible that additional load due to 
the use of mouse and keyboard on right upper extremities may have affected the activities of right sternocleidomastoid muscle.

Unlike previous investigations, in this study head neck postures were expressed using postural load index. This index calculates postural load based on the combination of non-neutral joint orientation and the corresponding duration. Most of the previous investigations have reported head neck postures in terms of averaged joint angle data. In these studies, head and neck postures were evaluated either for a relatively small section of experimental tasks (couple of seconds) (Burgess-Limerick et al., 1999) or by using indirect methods based on previously recorded video or photograph (Babski-Reeves et al., 2005; Turville et al., 1998b) or primarily in 2 D (Babski-Reeves et al., 2005; Burgess-Limerick et al., 1999; Turville et al., 1998b). In the present study a direct method was used for postural assessment and the data were recorded continuously during the testing tasks in 3D. It was found that users don't necessarily adopt exact similar postures while performing same task but rather operate in a certain range of motion and therefore averaging the kinematic data would not have represented the actual postures used by the users. Since the postural load index calculation, divide the motion trajectory into segments of motion and final postural load index calculation consider the intensity of the posture, it provides a comprehensive understanding of the postures used and a more accurate estimate of overall postural load. The postural loads quantified in this study matched very well with the muscle activity data, further validating this method of postural assessment. For example higher postural load by flexion during typing matched very well with the higher magnitude of EMG signal for the neck extensor (cervical trapezius) muscles. 


\subsection{Limitations and recommendation for future studies:}

There are a few limitations of this study that need to be acknowledged. The present study mainly examined the situation where dual screen monitors were arranged laterally making an angle of $180^{\circ}$. The keyboard and mouse were fixed centrally on a side out tray. Although this is one of the arrangement in which dual screen monitors can be used, a number of other arrangements are possible. Furthermore, different arrangements of keyboard and mouse with respect to the display screens are also possible. It is likely that each of these combinations may show different postural and muscle activity pattern. Future studies should examine effect of different arrangements of monitor screens, keyboard and mouse, and sitting surfaces. Only male participants were recruited in this study. Female office workers are known to be at a higher risk of neck and shoulder MSD than males. It is possible that females may adopt different posture and show altered muscle activity pattern while working with dual screen monitors. Future studies should examine combined effect of gender and different VDU layouts on the overall behavior of the neck shoulder musculature. The present study seemed to suggest that working on dual screen monitors may be more strenuous for neck and shoulder musculature than single screen monitor. These findings were based on a working duration of 30 minutes. It is possible that studied with longer working duration may reveal a different trend, especially for neuromuscular fatigue. Future studied should examine longer working duration, preferably 8 hour working day.

\subsection{Conclusions}

In the modern offices dual screen monitors are used with increasing frequency. Altered screen layout and increased desktop space associated with the dual screen monitors may affect working postures of head and neck and the activity of corresponding muscles. However, this problem was not investigated in the past. The results of the present study have shown that user 
adopted asymmetrical, more rotated, head and neck postures while working with dual screen monitors. Working postures and muscle activity pattern with respect to the monitor layout were found to depend on the type of the task. Typing task elicited higher postural and muscle activity load followed by search and find, and reading tasks. Independent of the tasks, right sternocleidomastoid muscle showed higher activity levels for dual screen layout. This increased activity levels may be due to increased head rotation associated with the dual screen monitors. 


\section{BIBLIOGRAPHY}

Aarås A., Horgen G., Bjørset H.H., Ro O., Walsøe H. (2001) Musculoskeletal, visual and psychosocial stress in VDU operators before and after multidisciplinary ergonomic interventions. A 6 years prospective study--Part II. Applied Ergonomics 32:559-571.

Acierno S., Baratta R., Solomonow M. (1995) A practical guide to electromyography for biomechanics. New Orleans: Louisiana State University.

Ariëns G., Bongers P., Douwes M., Miedema M., Hoogendoorn W., Van der Wal G., Bouter L., Van Mechelen W. (2001) Are neck flexion, neck rotation, and sitting at work risk factors for neck pain? Results of a prospective cohort study. Occupational and environmental medicine 58:200.

AS. (1990) Screen-based workstations, Part 2: Workstation Furniture (AS 3590, 2-1990), Standards Australia.

Babski-Reeves K., Stanfield J., Hughes L. (2005) Assessment of video display workstation set up on risk factors associated with the development of low back and neck discomfort. International Journal of Industrial Ergonomics 35:593-604.

Bergqvist U., Wolgast E., Nilsson B., Voss M. (1995) Musculoskeletal disorders among visual display terminal workers: individual, ergonomic, and work organizational factors. Ergonomics 38:763-776.

BLS. (2005) Most common uses for computers at work.

Burgess-Limerick R., Plooy A., Fraser K., Ankrum D. (1999) The influence of computer monitor height on head and neck posture. International Journal of Industrial Ergonomics 23:171179.

Burnett A., Green J., Netto K., Rodrigues J. (2007) Examination of EMG normalisation methods for the study of the posterior and posterolateral neck muscles in healthy controls. Journal of electromyography and kinesiology 17:635-641.

Chiu T., Ku W., Lee M., Sum W., Wan M., Wong C., Yuen C. (2002) A study on the prevalence of and risk factors for neck pain among university academic staff in Hong Kong. Journal of Occupational Rehabilitation 12:77-91.

Cook C., Burgess-Limerick R., Chang S. (2000) The prevalence of neck and upper extremity musculoskeletal symptoms in computer mouse users. International Journal of Industrial Ergonomics 26:347-356.

Finsen L. (1999) Biomechanical aspects of occupational neck postures during dental work. International Journal of Industrial Ergonomics 23:397-406.

Fostervold K.I., Aarås A., Lie I. (2006) Work with visual display units: Long-term health effects of high and downward line-of-sight in ordinary office environments. International Journal of Industrial Ergonomics 36:331-343.

Francisco J.M.H.D.S.J.S. (1992) Crippled by Computers.

Gerr F., Marcus M., Ortiz D. (1996) Methodological limitations in the study of video display terminal use and upper extremity musculoskeletal disorders. American journal of industrial medicine 29:649-656.

Gerr F., Marcus M., Ensor C., Kleinbaum D., Cohen S., Edwards A., Gentry E., Ortiz D., Monteilh C. (2002) A prospective study of computer users: I. Study design and incidence of musculoskeletal symptoms and disorders. American journal of industrial medicine 41:221-235. 
ISO. (1992) Ergonomic requirements for office work with visual display terminals (VDTs) -Workplace requirements (ISO 9241-3), International Organization for Standardization.

Jensen C., Ryholt C., Burr H., Villadsen E., Christensen H. (2002) Work-related psychosocial, physical and individual factors associated with musculoskeletal symptoms in computer users. Work \& Stress 16:107-120.

Johnston V., Souvlis T., Jimmieson N.L., Jull G. (2008) Associations between individual and workplace risk factors for self-reported neck pain and disability among female office workers. Applied Ergonomics 39:171-182.

Juul-Kristensen B., Kadefors R., Hansen K., Byström P., Sandsjö L., Sjøgaard G. (2006) Clinical signs and physical function in neck and upper extremities among elderly female computer users: the NEW study. European Journal of Applied Physiology 96:136-145.

Kietrys D., McClure P., Fitzgerald G. (1998) The relationship between head and neck posture and VDT screen height in keyboard operators. Physical Therapy 78:395.

Korhonen T., Ketola R., Toivonen R., Luukkonen R., Hakkanen M., Viikari-Juntura E. (2003) Work related and individual predictors for incident neck pain among office employees working with video display units. British Medical Journal 60:475.

Kothiyal K., Bjørnerem A.M. (2009) Effects of computer monitor setting on muscular activity, user comfort and acceptability in office work. Work: A Journal of Prevention, Assessment and Rehabilitation 32:155-163.

Marcus M., Gerr F., Monteilh C., Ortiz D.J., Gentry E., Cohen S., Edwards A., Ensor C., Kleinbaum D. (2002) A prospective study of computer users: II. Postural risk factors for musculoskeletal symptoms and disorders. American journal of industrial medicine 41:236-249.

Mathiassen S.E., Winkel J. (1990) Electromyographic activity in the shoulder-neck region according to arm position and glenohumeral torque. European journal of applied physiology and occupational physiology 61:370-379.

Nimbarte A. (2009) Modeling the Risk Factors Associated with the Neck Disorders During Manual Material Handling Tasks.

Nimbarte A.D., Aghazadeh F., Ikuma L.H., Harvey C.M. (2010) Neck Disorders among Construction Workers: Understanding the Physical Loads on the Cervical Spine during Static Lifting Tasks. Industrial Health 48:145-153.

NIOSH. (1999) NIOSH Publications on Video Display Terminals, U.S. Department Of Health and Human Servises, Cincinnati.

Psihogios J.P., Sommerich C.M., Mirka G.A., Moon S.D. (2001) A field evaluation of monitor placement effects in VDT users. Applied Ergonomics 32:313-325.

Punnett L., Bergqvist U. (1997) Visual display unit work and upper extremity musculoskeletal disorders. Arbete och hälsa 16:1-161.

Russell S.E., Wong K. (2005) Dual-Screen monitors: a qualitative analysis of their use in an academic library. The Journal of Academic Librarianship 31:574-577.

Saito S., Miyao M., Kondo T., Sakakibara H., Toyoshima H. (1997) Ergonomic evaluation of working posture of VDT operation using personal computer with flat panel display. Industrial health 35:264.

Sillanpaa J., Huikko S., Nyberg M., Kivi P., Laippala P., Uitti J. (2003) Effect of work with visual display units on musculo-skeletal disorders in the office environment. Occupational Medicine 53:443. 
Sommerich C., Joines S., Psihogios J. (2001a) Effects of computer monitor viewing angle and related factors on strain, performance, and preference outcomes. Human Factors 43:39.

Sommerich C.M., Joines S., Psihogios J.P. (2001b) Effects of computer monitor viewing angle and related factors on strain, performance, and preference outcomes. Human Factors: The Journal of the Human Factors and Ergonomics Society 43:39.

Szeto G.P., Lee R. (2002) An ergonomic evaluation comparing desktop, notebook, and subnotebook computers* 1 . Archives of physical medicine and rehabilitation 83:527-532.

Szeto G.P.Y., Sham K.S.W. (2008) The effects of angled positions of computer display screen on muscle activities of the neck-shoulder stabilizers. International Journal of Industrial Ergonomics 38:9-17.

Szeto G.P.Y., Straker L., Raine S. (2002) A field comparison of neck and shoulder postures in symptomatic and asymptomatic office workers. Applied Ergonomics 33:75-84.

Tobler N., Anderson J.A. (2004) Productivity and Multi-Screen Computer Displays. Rocky Mountain Communication:31.

Turville K., Psihogios J., Ulmer T., Mirka G. (1998a) The effects of video display terminal height on the operator: a comparison of the 15 and 40 recommendations. Applied Ergonomics 29:239-246.

Turville K.L., Psihogios J.P., Ulmer T.R., Mirka G.A. (1998b) The effects of video display terminal height on the operator: a comparison of the 15 and 40 recommendations. Applied Ergonomics 29:239-246.

Vasavada A., Li S., Delp S. (1998) Influence of muscle morphometry and moment arms on the moment-generating capacity of human neck muscles. Spine 23:412.

Villanueva M., Jonai H., Sotoyama M., Hisanaga N., Takeuchi Y., Saito S. (1997) Sitting posture and neck and shoulder muscle activities at different screen height settings of the visual display terminal. Industrial health 35:330-336.

Woods V. (2005) Musculoskeletal disorders and visual strain in intensive data processing workers. Occupational Medicine 55:121. 


\section{Appendix A - Consent form}

\section{WestVirginiaUniversity.}

Office of Research Compliance

\section{CONSENT AND INFORMATION FORM}

OMR ICF

Principal Investigator: Nimbarte, Ashish

Department: ENGINEERING - Ind./Mgt. Sys. Engineering

Tracking Number: H-22923

\section{Study Title:}

Effect of single/dual monitor use on behavior of neck-shoulder musculature

\section{Co-Investigator(s):}

AlAbdulmohsen, Rabab,

\section{Sponsor}

\section{Contact Persons}

In the event you experience any side effects or injury related to this research, you should contact Dr.Nimbarte at 304/293-9473. (After hours contact Dr.Nimbarte at 225/226-8813.)If you have any questions, concerns, or complaints about this research, you can contact Dr. Nimbarte at 304/293-9473 or Rabab alabdulmohsen at 304/282-9192.

For information regarding your rights as a research subject, you may contact the Office of Research Compliance at 304/293-7073.

Introduction You, have been asked to participate in this research study, which has been explained to you by Dr. AshishNimbarte, Ph.D., and Rabab Alabdulmohsen, B.S. This study is being conducted by Dr. Ashish Nimbarte, Ph.D. and Rabab Alabdulmohsen,B.S. in the Department of Industrial and Management Systems Engineering (IMSE) at West Virginia University. This research is being conducted to fulfill the requirements for a master thesis of Ms. Rabab Alabdulmohsen in the area of neck and shoulder

\begin{tabular}{|c|c|}
\hline Tracking \#: & H-22923 \\
\hline Approved Or & \\
\hline $\begin{array}{l}\text { Valid } \\
\text { Through: }\end{array}$ & $01 / 18 / 2011$ \\
\hline $\begin{array}{l}\text { Last } \\
\text { Amended: }\end{array}$ & 01/17/2012 \\
\hline
\end{tabular}

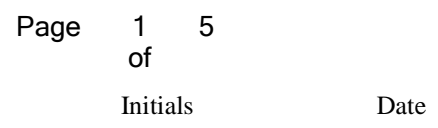


musculoskeletal disorders in the Department of IMSE at West Virginia University, under the supervision of Dr. Nimbarte.

\section{Purposes of the Study}

The purpose of this study is to understand the Effect of single/dual monitor use on behavior of neck-shoulder musculature. We expect to enroll approximately 40 subjects.

\section{Description of Procedures}

In this study effect of different monitor arrangement on the behavior of neck and shoulder region will be evaluated. You will perform computer work using different monitor arrangements. Five monitor arrangements will be studied. You will perform reading, typing and browsing type of tasks for a total duration of 30 minutes using each monitor arrangement. While working on the computer, position of the head and the activity of neck muscles will be recorded. The position of the head will be recorded using a motion analysis system and the activity of neck muscle will be recorded using surface electromyography. Surface electromyography is a technique, in which sensors are placed on the muscles of interest and electrical activity is recorded using a computer. There is no pain.

$\begin{array}{lllll}\text { Tracking \#: } & \mathrm{H}-22923 & \text { Page } \begin{array}{c}2 \\ \text { of }\end{array} & 5 & \\ \begin{array}{l}\text { Approved On: } \\ \text { Valid }\end{array} & \mathrm{N} / \mathrm{A} & & \text { Initials } & \text { Date } \\ \text { Through: } & 01 / 18 / 2011 & & & \\ \text { Last } & 01 / 17 / 2012 & & \\ \text { Amended: } & & & \end{array}$




\section{Risks and Discomforts}

There are no known or expected risks from participating in this study, except for the mild frustration associated with answering the questions during the search and find task.

Alternatives You do not have to participate in this study.

Benefits You will not receive any direct benefit from this study. The knowledge gained from this study may eventually benefit others.

Financial Considerations No monetary compensation will be given for participating in this study and participants do not incur any costs as a result of participation in the study. It is very important for you to understand that neither the investigator nor WVU or it associated affiliates has the funds set aside to pay for the cost of lost work wages or any care or treatment that might be necessary because you get hurt or sick taking part in this study. Any injuries that may result from this study would not be eligible for Workers 'Compensation as this is not joblated injury. Understand that any treatments necessary will be billed to the participant or to your personal health insurance, and you may wish to consult your insurance provider before participating in this study

$\begin{array}{lllll}\text { Tracking \#: } & \mathrm{H}-22923 & \text { Page } \begin{array}{c}3 \\ \text { of }\end{array} & 5 & \\ \begin{array}{l}\text { Approved On: } \\ \text { Valid }\end{array} & \mathrm{N} / \mathrm{A} & & \text { Initials } & \text { Date } \\ \text { Through: } & 01 / 18 / 2011 & & \\ \text { Last } & 01 / 17 / 2012 & & \\ \text { Amended: } & & & \end{array}$




\section{Confidentiality}

Any information about you that is obtained as a result of your participation in this research will be kept as confidential as legally possible. Your research records and test results, just like hospital records, may be subpoenaed by court order or may be inspected by federal regulatory authorities without your additional consent. In any publications that result from this research, neither your name nor any information from which you might be identified will be published without your consent

\section{Voluntary Participation}

Participation in this study is voluntary. You are free to withdraw your consent to participate in this study at any time. Refusal to participate or withdrawal will not affect your employee status at West Virginia University or your class standing or grades and will involve no penalty to you. In the event new information becomes available that may affect your willingness to participate in this study, this information will be given to you so that you can make an informed decision about whether or not to continue your participation. You have been given the opportunity to ask questions about the research, and you have received answers concerning areas you did not understand.

$\begin{array}{llllll}\text { Tracking \#: } & \mathrm{H}-22923 & \text { Page } \begin{array}{c}4 \\ \text { of }\end{array} & 5 & \text { Initials } & \text { Date } \\ \begin{array}{l}\text { Approved On: } \\ \text { Valid }\end{array} & \mathrm{N} / \mathrm{A} & & & \\ \text { Through: } & 01 / 18 / 2011 & & \\ \text { Last } & 01 / 17 / 2012 & & \\ \text { Amended: } & & & \end{array}$


Upon signing this form, you will receive a copy.

I willingly consent to participate in this research.

Signature of Subject or

Printed Name

Date

Time

Subjects Legal Representative

The participant has had the opportunity to have questions addressed. The participant willingly agrees to be in the study.

$\begin{array}{ll}\text { Tracking \#: } & \mathrm{H}-22923 \\ \text { Approved On: } & \mathrm{N} / \mathrm{A} \\ \text { Valid } & 01 / 18 / 2011 \\ \text { Through: } & \end{array}$

\section{Page $\begin{array}{cc}5 & 5 \\ \text { of }\end{array}$}

Initials Date 


\section{Appendix B - Computer program used for calculating postural loads}

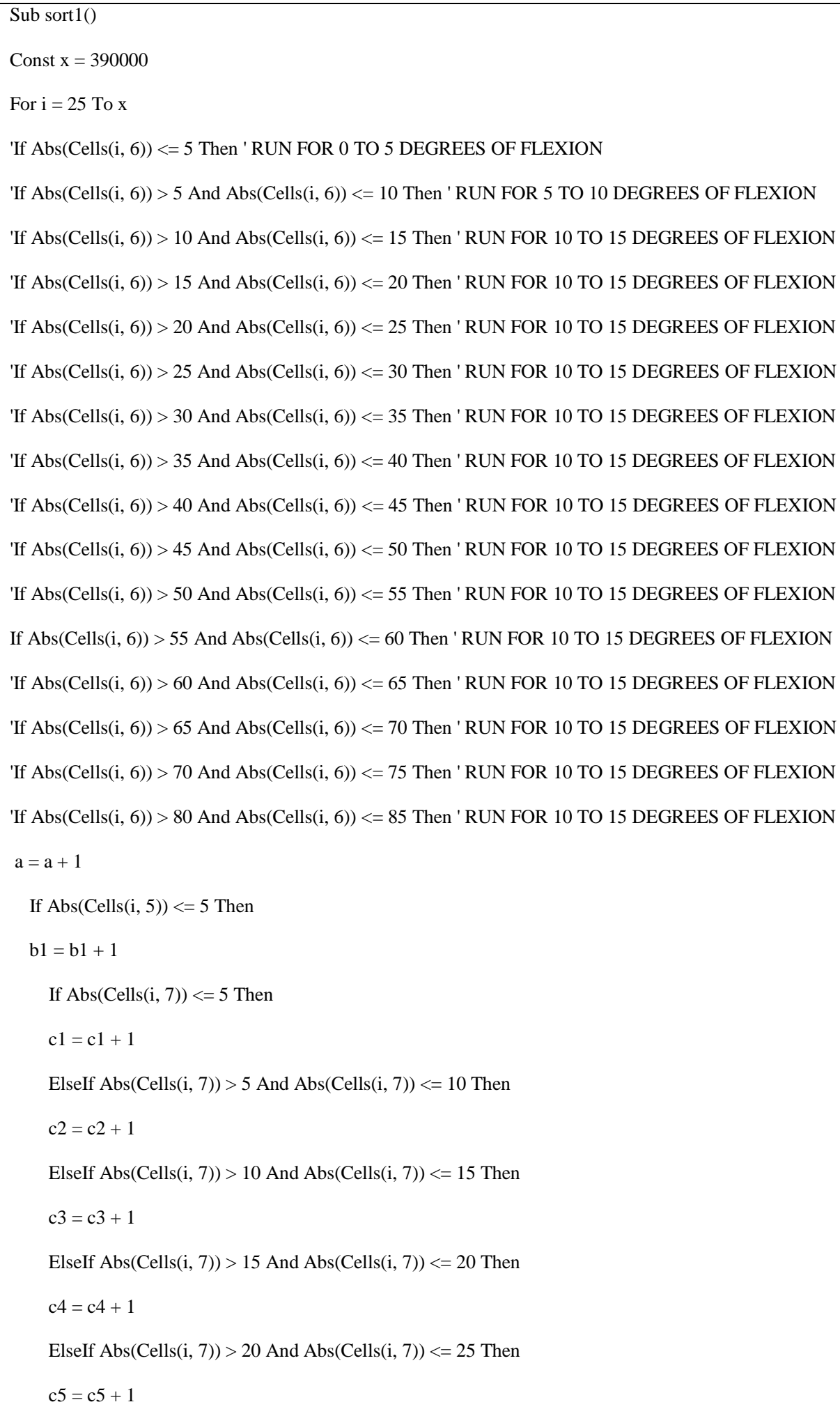




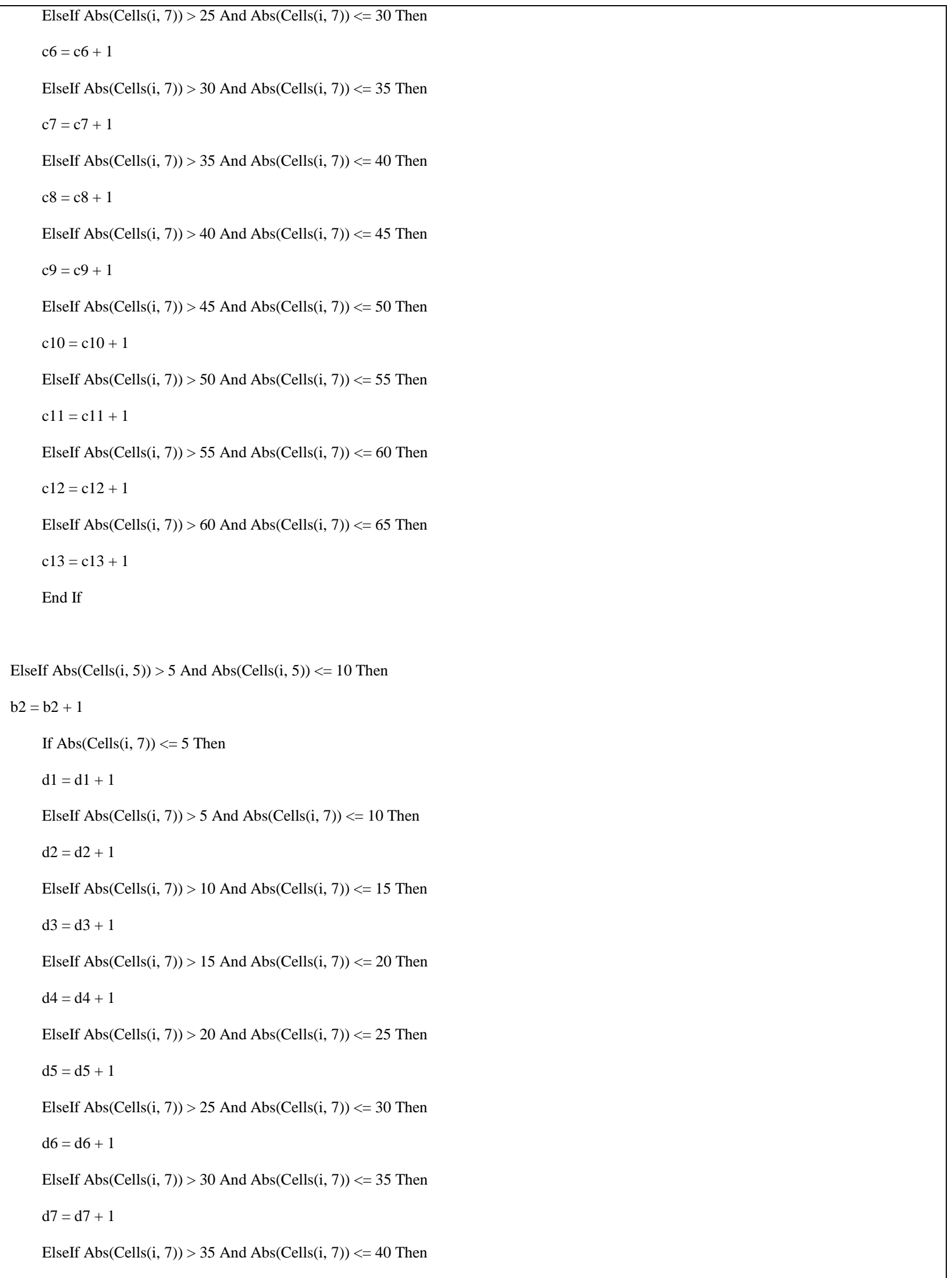


$\mathrm{d} 8=\mathrm{d} 8+1$

ElseIf Abs(Cells(i, 7)) > 40 And $\operatorname{Abs}(\operatorname{Cells}(\mathrm{i}, 7))<=45$ Then

$\mathrm{d} 9=\mathrm{d} 9+1$

ElseIf Abs(Cells (i, 7)) > 45 And $\operatorname{Abs}(\operatorname{Cells}(\mathrm{i}, 7))<=50$ Then

$\mathrm{d} 10=\mathrm{d} 10+1$

ElseIf $\operatorname{Abs}(\operatorname{Cells}(\mathrm{i}, 7))>50$ And $\operatorname{Abs}(\operatorname{Cells}(\mathrm{i}, 7))<=55$ Then

$\mathrm{d} 11=\mathrm{d} 11+1$

ElseIf $\operatorname{Abs}(\operatorname{Cells}(\mathrm{i}, 7))>55$ And $\operatorname{Abs}(\operatorname{Cells}(\mathrm{i}, 7))<=60$ Then

$\mathrm{d} 12=\mathrm{d} 12+1$

ElseIf $\operatorname{Abs}(\operatorname{Cells}(\mathrm{i}, 7))>60$ And $\operatorname{Abs}(\operatorname{Cells}(\mathrm{i}, 7))<=65$ Then

$\mathrm{d} 13=\mathrm{d} 13+1$

End If

ElseIf Abs(Cells(i, 5)) > 10 And $\operatorname{Abs}(\operatorname{Cells}(\mathrm{i}, 5))<=15$ Then

$\mathrm{b} 3=\mathrm{b} 3+1$

If $\operatorname{Abs}(\operatorname{Cells}(i, 7))<=5$ Then

$\mathrm{e} 1=\mathrm{e} 1+1$

ElseIf $\operatorname{Abs}(\operatorname{Cells}(i, 7))>5$ And $\operatorname{Abs}(\operatorname{Cells}(i, 7))<=10$ Then

$\mathrm{e} 2=\mathrm{e} 2+1$

ElseIf $\operatorname{Abs}(\operatorname{Cells}(\mathrm{i}, 7))>10$ And $\operatorname{Abs}(\operatorname{Cells}(\mathrm{i}, 7))<=15$ Then

$\mathrm{e} 3=\mathrm{e} 3+1$

ElseIf $\operatorname{Abs}(\operatorname{Cells}(\mathrm{i}, 7))>15$ And $\operatorname{Abs}(\operatorname{Cells}(\mathrm{i}, 7))<=20$ Then

$\mathrm{e} 4=\mathrm{e} 4+1$

ElseIf Abs(Cells(i, 7) $)>20$ And $\operatorname{Abs}(\operatorname{Cells}(\mathrm{i}, 7))<=25$ Then

$\mathrm{e} 5=\mathrm{e} 5+1$

ElseIf Abs(Cells(i, 7)) > 25 And $\operatorname{Abs}(\operatorname{Cells}(\mathrm{i}, 7))<=30$ Then

$\mathrm{e} 6=\mathrm{e} 6+1$

ElseIf $\operatorname{Abs}(\operatorname{Cells}(\mathrm{i}, 7))>30$ And $\operatorname{Abs}(\operatorname{Cells}(\mathrm{i}, 7))<=35$ Then

$\mathrm{e} 7=\mathrm{e} 7+1$

ElseIf $\operatorname{Abs}(\operatorname{Cells}(\mathrm{i}, 7))>35$ And $\operatorname{Abs}(\operatorname{Cells}(\mathrm{i}, 7))<=40$ Then

$\mathrm{e} 8=\mathrm{e} 8+1$

ElseIf $\operatorname{Abs}(\operatorname{Cells}(\mathrm{i}, 7))>40$ And $\operatorname{Abs}(\operatorname{Cells}(\mathrm{i}, 7))<=45$ Then

$e 9=e 9+1$

ElseIf $\operatorname{Abs}(\operatorname{Cells}(\mathrm{i}, 7))>45$ And $\operatorname{Abs}(\operatorname{Cells}(\mathrm{i}, 7))<=50$ Then

$\mathrm{e} 10=\mathrm{e} 10+1$

ElseIf $\operatorname{Abs}(\operatorname{Cells}(\mathrm{i}, 7))>50$ And $\operatorname{Abs}(\operatorname{Cells}(\mathrm{i}, 7))<=55$ Then 


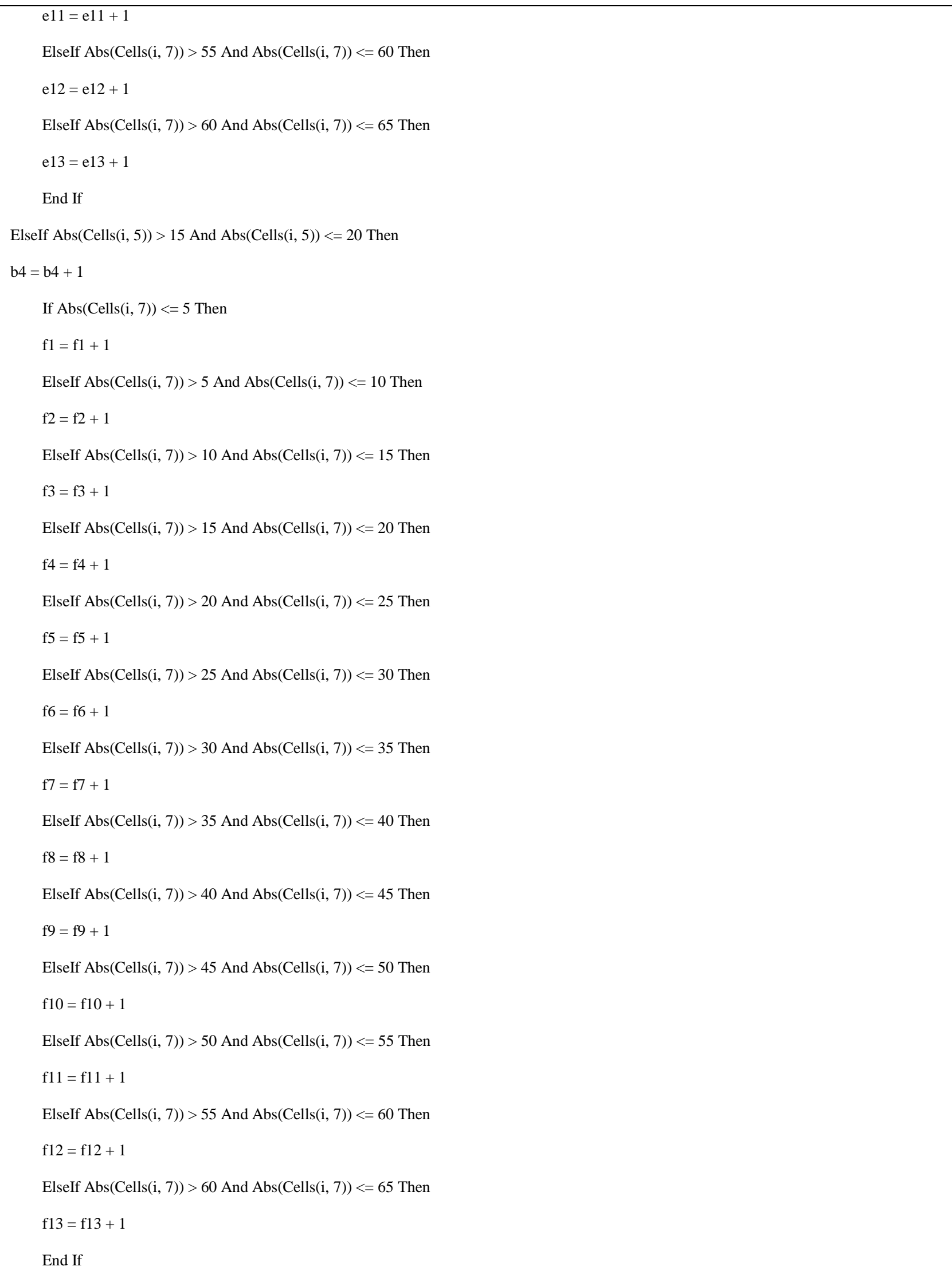


ElseIf $\operatorname{Abs}(\operatorname{Cells}(\mathrm{i}, 5))>20$ And $\operatorname{Abs}(\operatorname{Cells}(\mathrm{i}, 5))<=25$ Then

$\mathrm{b} 5=\mathrm{b} 5+1$

If $\operatorname{Abs}(\operatorname{Cells}(i, 7))<=5$ Then

$\mathrm{g} 1=\mathrm{g} 1+1$

ElseIf $\operatorname{Abs}(\operatorname{Cells}(i, 7))>5$ And $\operatorname{Abs}(\operatorname{Cells}(i, 7))<=10$ Then

$\mathrm{g} 2=\mathrm{g} 2+1$

ElseIf $\operatorname{Abs}(\operatorname{Cells}(\mathrm{i}, 7))>10$ And $\operatorname{Abs}(\operatorname{Cells}(\mathrm{i}, 7))<=15$ Then

$\mathrm{g} 3=\mathrm{g} 3+1$

ElseIf $\operatorname{Abs}(\operatorname{Cells}(\mathrm{i}, 7))>15$ And $\operatorname{Abs}(\operatorname{Cells}(\mathrm{i}, 7))<=20$ Then

$\mathrm{g} 4=\mathrm{g} 4+1$

ElseIf Abs(Cells(i, 7)) > 20 And $\operatorname{Abs}(\operatorname{Cells}(\mathrm{i}, 7))<=25$ Then

$\mathrm{g} 5=\mathrm{g} 5+1$

ElseIf $\operatorname{Abs}(\operatorname{Cells}(\mathrm{i}, 7))>25$ And $\operatorname{Abs}(\operatorname{Cells}(\mathrm{i}, 7))<=30$ Then

$\mathrm{g} 6=\mathrm{g} 6+1$

ElseIf $\operatorname{Abs}(\operatorname{Cells}(\mathrm{i}, 7))>30$ And $\mathrm{Abs}(\operatorname{Cells}(\mathrm{i}, 7))<=35$ Then

$\mathrm{g} 7=\mathrm{g} 7+1$

ElseIf $\operatorname{Abs}(\operatorname{Cells}(\mathrm{i}, 7))>35$ And $\operatorname{Abs}(\operatorname{Cells}(\mathrm{i}, 7))<=40$ Then

$\mathrm{g} 8=\mathrm{g} 8+1$

ElseIf Abs(Cells $(\mathrm{i}, 7))>40$ And $\operatorname{Abs}(\operatorname{Cells}(\mathrm{i}, 7))<=45$ Then

$\mathrm{g} 9=\mathrm{g} 9+1$

ElseIf $\operatorname{Abs}(\operatorname{Cells}(\mathrm{i}, 7))>45$ And $\operatorname{Abs}(\operatorname{Cells}(\mathrm{i}, 7))<=50$ Then

$\mathrm{g} 10=\mathrm{g} 10+1$

ElseIf $\operatorname{Abs}(\operatorname{Cells}(\mathrm{i}, 7))>50$ And $\operatorname{Abs}(\operatorname{Cells}(\mathrm{i}, 7))<=55$ Then

$\mathrm{g} 11=\mathrm{g} 11+1$

ElseIf $\operatorname{Abs}(\operatorname{Cells}(\mathrm{i}, 7))>55$ And $\operatorname{Abs}(\operatorname{Cells}(\mathrm{i}, 7))<=60$ Then

$\mathrm{g} 12=\mathrm{g} 12+1$

ElseIf $\operatorname{Abs}(\operatorname{Cells}(\mathrm{i}, 7))>60$ And $\operatorname{Abs}(\operatorname{Cells}(\mathrm{i}, 7))<=65$ Then

$\mathrm{g} 13=\mathrm{g} 13+1$

End If

ElseIf $\operatorname{Abs}(\operatorname{Cells}(\mathrm{i}, 5))>25 \operatorname{And} \operatorname{Abs}(\operatorname{Cells}(\mathrm{i}, 5))<=30$ Then

$\mathrm{b} 6=\mathrm{b} 6+1$

If $\operatorname{Abs}(\operatorname{Cells}(i, 7))<=5$ Then

$\mathrm{h} 1=\mathrm{h} 1+1$ 
Elself $\operatorname{Abs}(\operatorname{Cells}(\mathrm{i}, 7))>5$ And $\operatorname{Abs}(\operatorname{Cells}(\mathrm{i}, 7))<=10$ Then

$\mathrm{h} 2=\mathrm{h} 2+1$

ElseIf Abs(Cells(i, 7)) > 10 And $\operatorname{Abs}(\operatorname{Cells}(\mathrm{i}, 7))<=15$ Then

$\mathrm{h} 3=\mathrm{h} 3+1$

ElseIf Abs(Cells (i, 7)) > 15 And Abs(Cells(i, 7) $)<=20$ Then

$\mathrm{h} 4=\mathrm{h} 4+1$

ElseIf $\operatorname{Abs}(\operatorname{Cells}(\mathrm{i}, 7))>20$ And $\operatorname{Abs}(\operatorname{Cells}(\mathrm{i}, 7))<=25$ Then

$\mathrm{h} 5=\mathrm{h} 5+1$

ElseIf $\operatorname{Abs}(\operatorname{Cells}(\mathrm{i}, 7))>25$ And $\operatorname{Abs}(\operatorname{Cells}(\mathrm{i}, 7))<=30$ Then

$\mathrm{h} 6=\mathrm{h} 6+1$

ElseIf $\operatorname{Abs}(\operatorname{Cells}(\mathrm{i}, 7))>30$ And $\operatorname{Abs}(\operatorname{Cells}(\mathrm{i}, 7))<=35$ Then

$\mathrm{h} 7=\mathrm{h} 7+1$

ElseIf $\operatorname{Abs}(\operatorname{Cells}(\mathrm{i}, 7))>35$ And $\operatorname{Abs}(\operatorname{Cells}(\mathrm{i}, 7))<=40$ Then

$\mathrm{h} 8=\mathrm{h} 8+1$

ElseIf Abs(Cells(i, 7)) > 40 And Abs(Cells(i, 7)) $<=45$ Then

$\mathrm{h} 9=\mathrm{h} 9+1$

ElseIf $\operatorname{Abs}(\operatorname{Cells}(\mathrm{i}, 7))>45$ And $\mathrm{Abs}(\operatorname{Cells}(\mathrm{i}, 7))<=50$ Then

$\mathrm{h} 10=\mathrm{h} 10+1$

ElseIf Abs $(\operatorname{Cells}(\mathrm{i}, 7))>50$ And $\operatorname{Abs}(\operatorname{Cells}(\mathrm{i}, 7))<=55$ Then

$\mathrm{h} 11=\mathrm{h} 11+1$

ElseIf $\operatorname{Abs}(\operatorname{Cells}(\mathrm{i}, 7))>55$ And $\operatorname{Abs}(\operatorname{Cells}(\mathrm{i}, 7))<=60$ Then

$\mathrm{h} 12=\mathrm{h} 12+1$

ElseIf Abs(Cells(i, 7) $)>60$ And $\operatorname{Abs}(\operatorname{Cells}(\mathrm{i}, 7))<=65$ Then

$\mathrm{h} 13=\mathrm{h} 13+1$

End If

ElseIf Abs(Cells(i, 5)) > 30 And $\operatorname{Abs}(\operatorname{Cells}(\mathrm{i}, 5))<=35$ Then

$\mathrm{b} 7=\mathrm{b} 7+1$

If $\operatorname{Abs}(\operatorname{Cells}(\mathrm{i}, 7))<=5$ Then

$\mathrm{i} 1=\mathrm{i} 1+1$

ElseIf $\operatorname{Abs}(\operatorname{Cells}(\mathrm{i}, 7))>5$ And $\operatorname{Abs}(\operatorname{Cells}(\mathrm{i}, 7))<=10$ Then

$\mathrm{i} 2=\mathrm{i} 2+1$

ElseIf $\operatorname{Abs}(\operatorname{Cells}(\mathrm{i}, 7))>10$ And $\operatorname{Abs}(\operatorname{Cells}(\mathrm{i}, 7))<=15$ Then

$\mathrm{i} 3=\mathrm{i} 3+1$

ElseIf $\operatorname{Abs}(\operatorname{Cells}(\mathrm{i}, 7))>15$ And $\operatorname{Abs}(\operatorname{Cells}(\mathrm{i}, 7))<=20$ Then

$\mathrm{i} 4=\mathrm{i} 4+1$ 
Elself Abs(Cells(i, 7)) > 20 And Abs(Cells(i, 7)) <= 25 Then $\mathrm{i} 5=\mathrm{i} 5+1$

ElseIf Abs(Cells(i, 7) $)>25$ And $\operatorname{Abs}(\operatorname{Cells}(\mathrm{i}, 7))<=30$ Then $\mathrm{i} 6=\mathrm{i} 6+1$

ElseIf Abs(Cells (i, 7)) > 30 And $\operatorname{Abs}(\operatorname{Cells}(\mathrm{i}, 7))<=35$ Then $\mathrm{i} 7=\mathrm{i} 7+1$

ElseIf $\operatorname{Abs}(\operatorname{Cells}(\mathrm{i}, 7))>35$ And $\operatorname{Abs}(\operatorname{Cells}(\mathrm{i}, 7))<=40$ Then $\mathrm{i} 8=\mathrm{i} 8+1$

ElseIf $\operatorname{Abs}(\operatorname{Cells}(\mathrm{i}, 7))>40$ And $\operatorname{Abs}(\operatorname{Cells}(\mathrm{i}, 7))<=45$ Then

$\mathrm{i} 9=\mathrm{i} 9+1$

ElseIf $\operatorname{Abs}(\operatorname{Cells}(\mathrm{i}, 7))>45$ And $\operatorname{Abs}(\operatorname{Cells}(\mathrm{i}, 7))<=50$ Then

$\mathrm{i} 10=\mathrm{i} 10+1$

ElseIf $\operatorname{Abs}(\operatorname{Cells}(\mathrm{i}, 7))>50$ And $\operatorname{Abs}(\operatorname{Cells}(\mathrm{i}, 7))<=55$ Then

$\mathrm{i} 11=\mathrm{i} 11+1$

ElseIf Abs(Cells(i, 7) $)>55$ And Abs(Cells $(\mathrm{i}, 7))<=60$ Then

$\mathrm{i} 12=\mathrm{i} 12+1$

ElseIf $\operatorname{Abs}(\operatorname{Cells}(\mathrm{i}, 7))>60$ And $\operatorname{Abs}(\operatorname{Cells}(\mathrm{i}, 7))<=65$ Then

$\mathrm{i} 13=\mathrm{i} 13+1$

End If

ElseIf Abs(Cells(i, 5)) $>35$ And Abs(Cells(i, 5)) $<=40$ Then $\mathrm{b} 8=\mathrm{b} 8+1$

If $\operatorname{Abs}(\operatorname{Cells}(i, 7))<=5$ Then

$\mathrm{j} 1=\mathrm{j} 1+1$

ElseIf $\operatorname{Abs}(\operatorname{Cells}(\mathrm{i}, 7))>5$ And $\operatorname{Abs}(\operatorname{Cells}(\mathrm{i}, 7))<=10$ Then $\mathrm{j} 2=\mathrm{j} 2+1$

ElseIf Abs(Cells $(\mathrm{i}, 7))>10$ And $\operatorname{Abs}(\operatorname{Cells}(\mathrm{i}, 7))<=15$ Then $\mathrm{j} 3=\mathrm{j} 3+1$

ElseIf $\operatorname{Abs}(\operatorname{Cells}(\mathrm{i}, 7))>15$ And $\operatorname{Abs}(\operatorname{Cells}(\mathrm{i}, 7))<=20$ Then

$\mathrm{j} 4=\mathrm{j} 4+1$

ElseIf $\operatorname{Abs}(\operatorname{Cells}(\mathrm{i}, 7))>20$ And $\operatorname{Abs}(\operatorname{Cells}(\mathrm{i}, 7))<=25$ Then

$\mathrm{j} 5=\mathrm{j} 5+1$

ElseIf $\operatorname{Abs}(\operatorname{Cells}(\mathrm{i}, 7))>25$ And $\operatorname{Abs}(\operatorname{Cells}(\mathrm{i}, 7))<=30$ Then

$\mathrm{j} 6=\mathrm{j} 6+1$

ElseIf $\operatorname{Abs}(\operatorname{Cells}(\mathrm{i}, 7))>30$ And $\operatorname{Abs}(\operatorname{Cells}(\mathrm{i}, 7))<=35$ Then

$\mathrm{j} 7=\mathrm{j} 7+1$ 
Elself Abs(Cells(i, 7)) > 35 And Abs(Cells(i, 7)) <= 40 Then $\mathrm{j} 8=\mathrm{j} 8+1$

ElseIf Abs $(\operatorname{Cells}(\mathrm{i}, 7))>40$ And $\operatorname{Abs}(\operatorname{Cells}(\mathrm{i}, 7))<=45$ Then

$\mathrm{j} 9=\mathrm{j} 9+1$

ElseIf Abs $(\operatorname{Cells}(\mathrm{i}, 7))>45 \operatorname{And} \operatorname{Abs}(\operatorname{Cells}(\mathrm{i}, 7))<=50$ Then

$\mathrm{j} 10=\mathrm{j} 10+1$

ElseIf $\operatorname{Abs}(\operatorname{Cells}(\mathrm{i}, 7))>50$ And $\operatorname{Abs}(\operatorname{Cells}(\mathrm{i}, 7))<=55$ Then

$\mathrm{j} 11=\mathrm{j} 11+1$

ElseIf $\operatorname{Abs}(\operatorname{Cells}(\mathrm{i}, 7))>55$ And $\operatorname{Abs}(\operatorname{Cells}(\mathrm{i}, 7))<=60$ Then

$\mathrm{j} 12=\mathrm{j} 12+1$

ElseIf $\operatorname{Abs}(\operatorname{Cells}(\mathrm{i}, 7))>60$ And $\operatorname{Abs}(\operatorname{Cells}(\mathrm{i}, 7))<=65$ Then

$\mathrm{j} 13=\mathrm{j} 13+1$

End If

ElseIf Abs(Cells(i, 5)) > 40 And $\operatorname{Abs}(\operatorname{Cells}(\mathrm{i}, 5))<=45$ Then

$\mathrm{b} 9=\mathrm{b} 9+1$

If $\operatorname{Abs}(\operatorname{Cells}(\mathrm{i}, 7))<=5$ Then

$\mathrm{k} 1=\mathrm{k} 1+1$

ElseIf Abs(Cells(i, 7)) $>5$ And Abs(Cells $(\mathrm{i}, 7))<=10$ Then

$\mathrm{k} 2=\mathrm{k} 2+1$

ElseIf Abs(Cells(i, 7)) > 10 And Abs(Cells(i, 7)) <= 15 Then

$\mathrm{k} 3=\mathrm{k} 3+1$

ElseIf Abs(Cells(i, 7) $)>15$ And $\operatorname{Abs}(\operatorname{Cells}(\mathrm{i}, 7))<=20$ Then

$\mathrm{k} 4=\mathrm{k} 4+1$

ElseIf Abs $(\operatorname{Cells}(\mathrm{i}, 7))>20$ And $\operatorname{Abs}(\operatorname{Cells}(\mathrm{i}, 7))<=25$ Then

$\mathrm{k} 5=\mathrm{k} 5+1$

ElseIf $\operatorname{Abs}(\operatorname{Cells}(\mathrm{i}, 7))>25$ And $\operatorname{Abs}(\operatorname{Cells}(\mathrm{i}, 7))<=30$ Then

$\mathrm{k} 6=\mathrm{k} 6+1$

ElseIf $\operatorname{Abs}(\operatorname{Cells}(\mathrm{i}, 7))>30$ And $\operatorname{Abs}(\operatorname{Cells}(\mathrm{i}, 7))<=35$ Then

$\mathrm{k} 7=\mathrm{k} 7+1$

ElseIf $\operatorname{Abs}(\operatorname{Cells}(\mathrm{i}, 7))>35$ And $\operatorname{Abs}(\operatorname{Cells}(\mathrm{i}, 7))<=40$ Then

$\mathrm{k} 8=\mathrm{k} 8+1$

ElseIf $\operatorname{Abs}(\operatorname{Cells}(\mathrm{i}, 7))>40$ And $\operatorname{Abs}(\operatorname{Cells}(\mathrm{i}, 7))<=45$ Then

$\mathrm{k} 9=\mathrm{k} 9+1$

ElseIf $\operatorname{Abs}(\operatorname{Cells}(\mathrm{i}, 7))>45$ And $\operatorname{Abs}(\operatorname{Cells}(\mathrm{i}, 7))<=50$ Then

$\mathrm{k} 10=\mathrm{k} 10+1$ 
Elself Abs(Cells(i, 7)) > 50 And Abs(Cells(i, 7)) <= 55 Then $\mathrm{k} 11=\mathrm{k} 11+1$

ElseIf $\operatorname{Abs}(\operatorname{Cells}(\mathrm{i}, 7))>55$ And $\operatorname{Abs}(\operatorname{Cells}(\mathrm{i}, 7))<=60$ Then $\mathrm{k} 12=\mathrm{k} 12+1$

ElseIf Abs(Cells $(\mathrm{i}, 7))>60$ And $\operatorname{Abs}(\operatorname{Cells}(\mathrm{i}, 7))<=65$ Then $\mathrm{k} 13=\mathrm{k} 13+1$

End If

ElseIf Abs(Cells(i, 5)) > 45 And $\operatorname{Abs}(\operatorname{Cells}(\mathrm{i}, 5))<=50$ Then $\mathrm{b} 10=\mathrm{b} 10+1$

If $\operatorname{Abs}(\operatorname{Cells}(i, 7))<=5$ Then

$11=11+1$

ElseIf Abs(Cells(i, 7)) $>5$ And $\operatorname{Abs}(\operatorname{Cells}(\mathrm{i}, 7))<=10$ Then

$12=12+1$

ElseIf $\operatorname{Abs}(\operatorname{Cells}(\mathrm{i}, 7))>10$ And $\operatorname{Abs}(\operatorname{Cells}(\mathrm{i}, 7))<=15$ Then

$13=13+1$

ElseIf $\operatorname{Abs}(\operatorname{Cells}(\mathrm{i}, 7))>15$ And $\operatorname{Abs}(\operatorname{Cells}(\mathrm{i}, 7))<=20$ Then

$14=14+1$

ElseIf $\operatorname{Abs}(\operatorname{Cells}(\mathrm{i}, 7))>20$ And $\operatorname{Abs}(\operatorname{Cells}(\mathrm{i}, 7))<=25$ Then

$15=15+1$

ElseIf $\operatorname{Abs}(\operatorname{Cells}(\mathrm{i}, 7))>25$ And $\operatorname{Abs}(\operatorname{Cells}(\mathrm{i}, 7))<=30$ Then

$16=16+1$

ElseIf Abs(Cells(i, 7) $)>30$ And $\operatorname{Abs}(\operatorname{Cells}(\mathrm{i}, 7))<=35$ Then $17=17+1$

ElseIf Abs(Cells (i, 7)) > 35 And Abs(Cells(i, 7) $)<=40$ Then $18=18+1$

ElseIf Abs(Cells $(\mathrm{i}, 7))>40$ And $\operatorname{Abs}(\operatorname{Cells}(\mathrm{i}, 7))<=45$ Then $19=19+1$

ElseIf $\operatorname{Abs}(\operatorname{Cells}(\mathrm{i}, 7))>45$ And $\operatorname{Abs}(\operatorname{Cells}(\mathrm{i}, 7))<=50$ Then

$110=110+1$

ElseIf $\operatorname{Abs}(\operatorname{Cells}(\mathrm{i}, 7))>50$ And $\operatorname{Abs}(\operatorname{Cells}(\mathrm{i}, 7))<=55$ Then

$111=111+1$

ElseIf $\operatorname{Abs}(\operatorname{Cells}(\mathrm{i}, 7))>55$ And $\operatorname{Abs}(\operatorname{Cells}(\mathrm{i}, 7))<=60$ Then

$112=112+1$

ElseIf $\operatorname{Abs}(\operatorname{Cells}(\mathrm{i}, 7))>60$ And $\operatorname{Abs}(\operatorname{Cells}(\mathrm{i}, 7))<=65$ Then

$113=113+1$ 


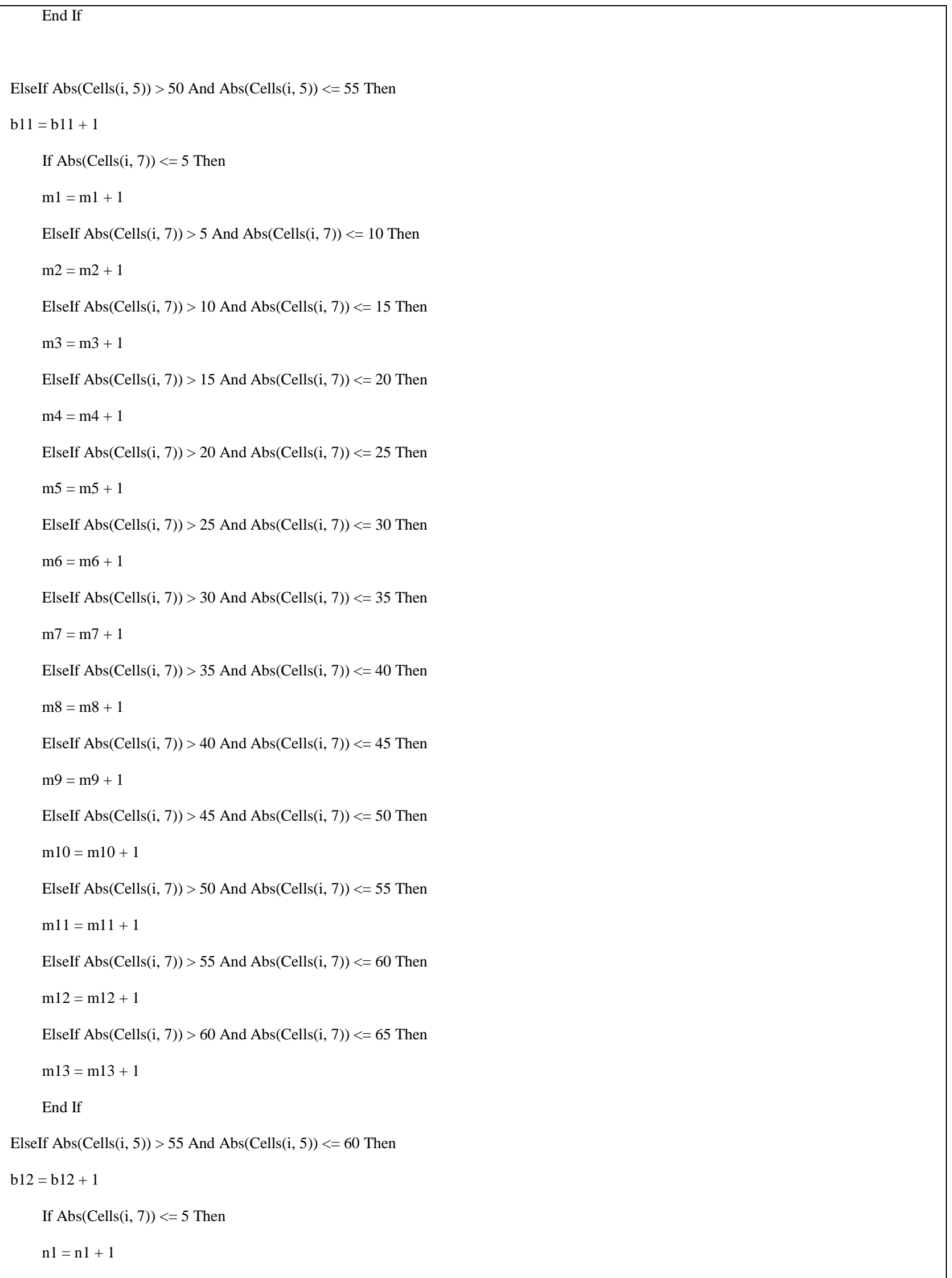


Elself $\operatorname{Abs}(\operatorname{Cells}(\mathrm{i}, 7))>5$ And $\operatorname{Abs}(\operatorname{Cells}(\mathrm{i}, 7))<=10$ Then

$\mathrm{n} 2=\mathrm{n} 2+1$

ElseIf Abs(Cells(i, 7)) > 10 And $\operatorname{Abs}(\operatorname{Cells}(\mathrm{i}, 7))<=15$ Then

$\mathrm{n} 3=\mathrm{n} 3+1$

ElseIf Abs(Cells (i, 7)) > 15 And $\operatorname{Abs}(\operatorname{Cells}(\mathrm{i}, 7))<=20$ Then

$\mathrm{n} 4=\mathrm{n} 4+1$

ElseIf $\operatorname{Abs}(\operatorname{Cells}(\mathrm{i}, 7))>20$ And $\operatorname{Abs}(\operatorname{Cells}(\mathrm{i}, 7))<=25$ Then

$\mathrm{n} 5=\mathrm{n} 5+1$

ElseIf $\operatorname{Abs}(\operatorname{Cells}(\mathrm{i}, 7))>25$ And $\operatorname{Abs}(\operatorname{Cells}(\mathrm{i}, 7))<=30$ Then

$\mathrm{n} 6=\mathrm{n} 6+1$

ElseIf $\operatorname{Abs}(\operatorname{Cells}(\mathrm{i}, 7))>30$ And $\operatorname{Abs}(\operatorname{Cells}(\mathrm{i}, 7))<=35$ Then

$\mathrm{n} 7=\mathrm{n} 7+1$

ElseIf $\operatorname{Abs}(\operatorname{Cells}(\mathrm{i}, 7))>35$ And $\operatorname{Abs}(\operatorname{Cells}(\mathrm{i}, 7))<=40$ Then

$\mathrm{n} 8=\mathrm{n} 8+1$

ElseIf Abs(Cells(i, 7) $)>40$ And Abs(Cells $(\mathrm{i}, 7))<=45$ Then

$\mathrm{n} 9=\mathrm{n} 9+1$

ElseIf $\operatorname{Abs}(\operatorname{Cells}(\mathrm{i}, 7))>45$ And $\mathrm{Abs}(\operatorname{Cells}(\mathrm{i}, 7))<=50$ Then

$\mathrm{n} 10=\mathrm{n} 10+1$

ElseIf $\operatorname{Abs}(\operatorname{Cells}(\mathrm{i}, 7))>50$ And $\operatorname{Abs}(\operatorname{Cells}(\mathrm{i}, 7))<=55$ Then

$\mathrm{n} 11=\mathrm{n} 11+1$

ElseIf $\operatorname{Abs}(\operatorname{Cells}(\mathrm{i}, 7))>55$ And $\operatorname{Abs}(\operatorname{Cells}(\mathrm{i}, 7))<=60$ Then

$\mathrm{n} 12=\mathrm{n} 12+1$

ElseIf Abs(Cells(i, 7) $)>60$ And $\operatorname{Abs}(\operatorname{Cells}(\mathrm{i}, 7))<=65$ Then

$\mathrm{n} 13=\mathrm{n} 13+1$

End If

ElseIf $\operatorname{Abs}(\operatorname{Cells}(\mathrm{i}, 5))>60$ And $\operatorname{Abs}(\operatorname{Cells}(\mathrm{i}, 5))<=65$ Then

$\mathrm{b} 13=\mathrm{b} 13+1$

If $\operatorname{Abs}(\operatorname{Cells}(i, 7))<=5$ Then

$\mathrm{o} 1=\mathrm{o} 1+1$

ElseIf $\operatorname{Abs}(\operatorname{Cells}(\mathrm{i}, 7))>5$ And $\operatorname{Abs}(\operatorname{Cells}(\mathrm{i}, 7))<=10$ Then

$02=02+1$

ElseIf $\operatorname{Abs}(\operatorname{Cells}(\mathrm{i}, 7))>10$ And $\operatorname{Abs}(\operatorname{Cells}(\mathrm{i}, 7))<=15$ Then

$03=03+1$

ElseIf $\operatorname{Abs}(\operatorname{Cells}(\mathrm{i}, 7))>15$ And $\operatorname{Abs}(\operatorname{Cells}(\mathrm{i}, 7))<=20$ Then

$\mathrm{o} 4=\mathrm{o} 4+1$ 
Elself Abs(Cells(i, 7)) > 20 And Abs(Cells(i, 7)) <= 25 Then $05=05+1$

ElseIf Abs(Cells(i, 7) $)>25$ And $\operatorname{Abs}(\operatorname{Cells}(\mathrm{i}, 7))<=30$ Then

$06=06+1$

ElseIf Abs(Cells (i, 7)) > 30 And Abs(Cells(i, 7) $)<=35$ Then

$07=07+1$

ElseIf $\operatorname{Abs}(\operatorname{Cells}(\mathrm{i}, 7))>35$ And $\operatorname{Abs}(\operatorname{Cells}(\mathrm{i}, 7))<=40$ Then

$08=08+1$

ElseIf $\operatorname{Abs}(\operatorname{Cells}(\mathrm{i}, 7))>40$ And $\operatorname{Abs}(\operatorname{Cells}(\mathrm{i}, 7))<=45$ Then

$09=09+1$

ElseIf Abs(Cells(i, 7)) > 45 And $\operatorname{Abs}(\operatorname{Cells}(\mathrm{i}, 7))<=50$ Then

$\mathrm{o} 10=\mathrm{o} 10+1$

ElseIf $\operatorname{Abs}(\operatorname{Cells}(\mathrm{i}, 7))>50$ And $\operatorname{Abs}(\operatorname{Cells}(\mathrm{i}, 7))<=55$ Then

$011=011+1$

ElseIf Abs(Cells(i, 7) $)>55$ And Abs(Cells $(\mathrm{i}, 7))<=60$ Then

$012=012+1$

ElseIf $\operatorname{Abs}(\operatorname{Cells}(\mathrm{i}, 7))>60$ And $\operatorname{Abs}(\operatorname{Cells}(\mathrm{i}, 7))<=65$ Then

$\mathrm{o} 13=\mathrm{o} 13+1$

End If

ElseIf Abs(Cells(i, 5)) $>65$ And Abs(Cells(i, 5)) $<=70$ Then

$\mathrm{b} 14=\mathrm{b} 14+1$

If $\operatorname{Abs}(\operatorname{Cells}(i, 7))<=5$ Then

$\mathrm{p} 1=\mathrm{p} 1+1$

ElseIf $\operatorname{Abs}(\operatorname{Cells}(\mathrm{i}, 7))>5$ And $\operatorname{Abs}(\operatorname{Cells}(\mathrm{i}, 7))<=10$ Then

$\mathrm{p} 2=\mathrm{p} 2+1$

ElseIf Abs(Cells $(\mathrm{i}, 7))>10$ And $\operatorname{Abs}(\operatorname{Cells}(\mathrm{i}, 7))<=15$ Then

$\mathrm{p} 3=\mathrm{p} 3+1$

ElseIf $\operatorname{Abs}(\operatorname{Cells}(\mathrm{i}, 7))>15$ And $\operatorname{Abs}(\operatorname{Cells}(\mathrm{i}, 7))<=20$ Then

$\mathrm{p} 4=\mathrm{p} 4+1$

ElseIf $\operatorname{Abs}(\operatorname{Cells}(\mathrm{i}, 7))>20$ And $\operatorname{Abs}(\operatorname{Cells}(\mathrm{i}, 7))<=25$ Then

$\mathrm{p} 5=\mathrm{p} 5+1$

ElseIf $\operatorname{Abs}(\operatorname{Cells}(\mathrm{i}, 7))>25$ And $\operatorname{Abs}(\operatorname{Cells}(\mathrm{i}, 7))<=30$ Then

$\mathrm{p} 6=\mathrm{p} 6+1$

ElseIf $\operatorname{Abs}(\operatorname{Cells}(\mathrm{i}, 7))>30$ And $\operatorname{Abs}(\operatorname{Cells}(\mathrm{i}, 7))<=35$ Then

$\mathrm{p} 7=\mathrm{p} 7+1$ 
Elself Abs(Cells(i, 7)) > 35 And Abs(Cells(i, 7)) <= 40 Then $\mathrm{p} 8=\mathrm{p} 8+1$

ElseIf Abs(Cells(i, 7) $)>40$ And $\operatorname{Abs}(\operatorname{Cells}(\mathrm{i}, 7))<=45$ Then $\mathrm{p} 9=\mathrm{p} 9+1$

ElseIf Abs $(\operatorname{Cells}(\mathrm{i}, 7))>45 \operatorname{And} \operatorname{Abs}(\operatorname{Cells}(\mathrm{i}, 7))<=50$ Then $\mathrm{p} 10=\mathrm{p} 10+1$

ElseIf $\operatorname{Abs}(\operatorname{Cells}(\mathrm{i}, 7))>50$ And $\operatorname{Abs}(\operatorname{Cells}(\mathrm{i}, 7))<=55$ Then $\mathrm{p} 11=\mathrm{p} 11+1$

ElseIf $\operatorname{Abs}(\operatorname{Cells}(\mathrm{i}, 7))>55$ And $\operatorname{Abs}(\operatorname{Cells}(\mathrm{i}, 7))<=60$ Then $\mathrm{p} 12=\mathrm{p} 12+1$

ElseIf $\operatorname{Abs}(\operatorname{Cells}(\mathrm{i}, 7))>60$ And $\operatorname{Abs}(\operatorname{Cells}(\mathrm{i}, 7))<=65$ Then $\mathrm{p} 13=\mathrm{p} 13+1$

End If

ElseIf Abs(Cells(i, 5)) > 75 And Abs(Cells(i, 5)) $<=80$ Then $\mathrm{b} 15=\mathrm{b} 15+1$

If $\operatorname{Abs}(\operatorname{Cells}(i, 7))<=5$ Then

$\mathrm{q} 1=\mathrm{q} 1+1$

ElseIf $\operatorname{Abs}(\operatorname{Cells}(i, 7))>5$ And $\operatorname{Abs}(\operatorname{Cells}(i, 7))<=10$ Then

$\mathrm{q} 2=\mathrm{q} 2+1$

ElseIf $\operatorname{Abs}(\operatorname{Cells}(\mathrm{i}, 7))>10$ And $\operatorname{Abs}(\operatorname{Cells}(\mathrm{i}, 7))<=15$ Then $\mathrm{q} 3=\mathrm{q} 3+1$

ElseIf Abs(Cells(i, 7) $)>15$ And $\operatorname{Abs}(\operatorname{Cells}(\mathrm{i}, 7))<=20$ Then $\mathrm{q} 4=\mathrm{q} 4+1$

ElseIf Abs $(\operatorname{Cells}(\mathrm{i}, 7))>20$ And $\operatorname{Abs}(\operatorname{Cells}(\mathrm{i}, 7))<=25$ Then $\mathrm{q} 5=\mathrm{q} 5+1$

ElseIf Abs(Cells (i, 7)) > 25 And $\operatorname{Abs}(\operatorname{Cells}(\mathrm{i}, 7))<=30$ Then $\mathrm{q} 6=\mathrm{q} 6+1$

ElseIf $\operatorname{Abs}(\operatorname{Cells}(\mathrm{i}, 7))>30$ And $\operatorname{Abs}(\operatorname{Cells}(\mathrm{i}, 7))<=35$ Then $\mathrm{q} 7=\mathrm{q} 7+1$

ElseIf $\operatorname{Abs}(\operatorname{Cells}(\mathrm{i}, 7))>35$ And $\operatorname{Abs}(\operatorname{Cells}(\mathrm{i}, 7))<=40$ Then $\mathrm{q} 8=\mathrm{q} 8+1$

ElseIf $\operatorname{Abs}(\operatorname{Cells}(\mathrm{i}, 7))>40$ And $\operatorname{Abs}(\operatorname{Cells}(\mathrm{i}, 7))<=45$ Then $\mathrm{q} 9=\mathrm{q} 9+1$

ElseIf $\operatorname{Abs}(\operatorname{Cells}(\mathrm{i}, 7))>45$ And $\operatorname{Abs}(\operatorname{Cells}(\mathrm{i}, 7))<=50$ Then $\mathrm{q} 10=\mathrm{q} 10+1$ 


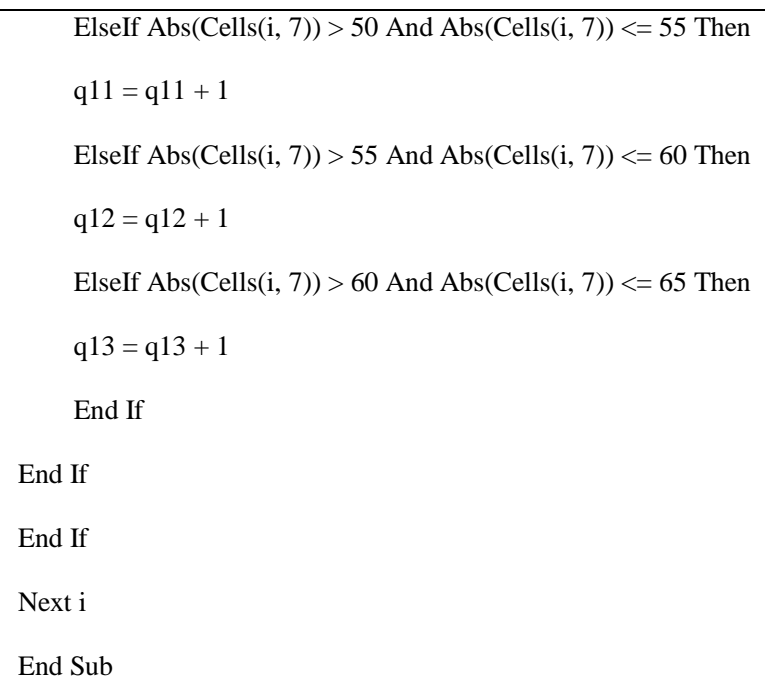


Appendix C - Normal probability plot of residuals
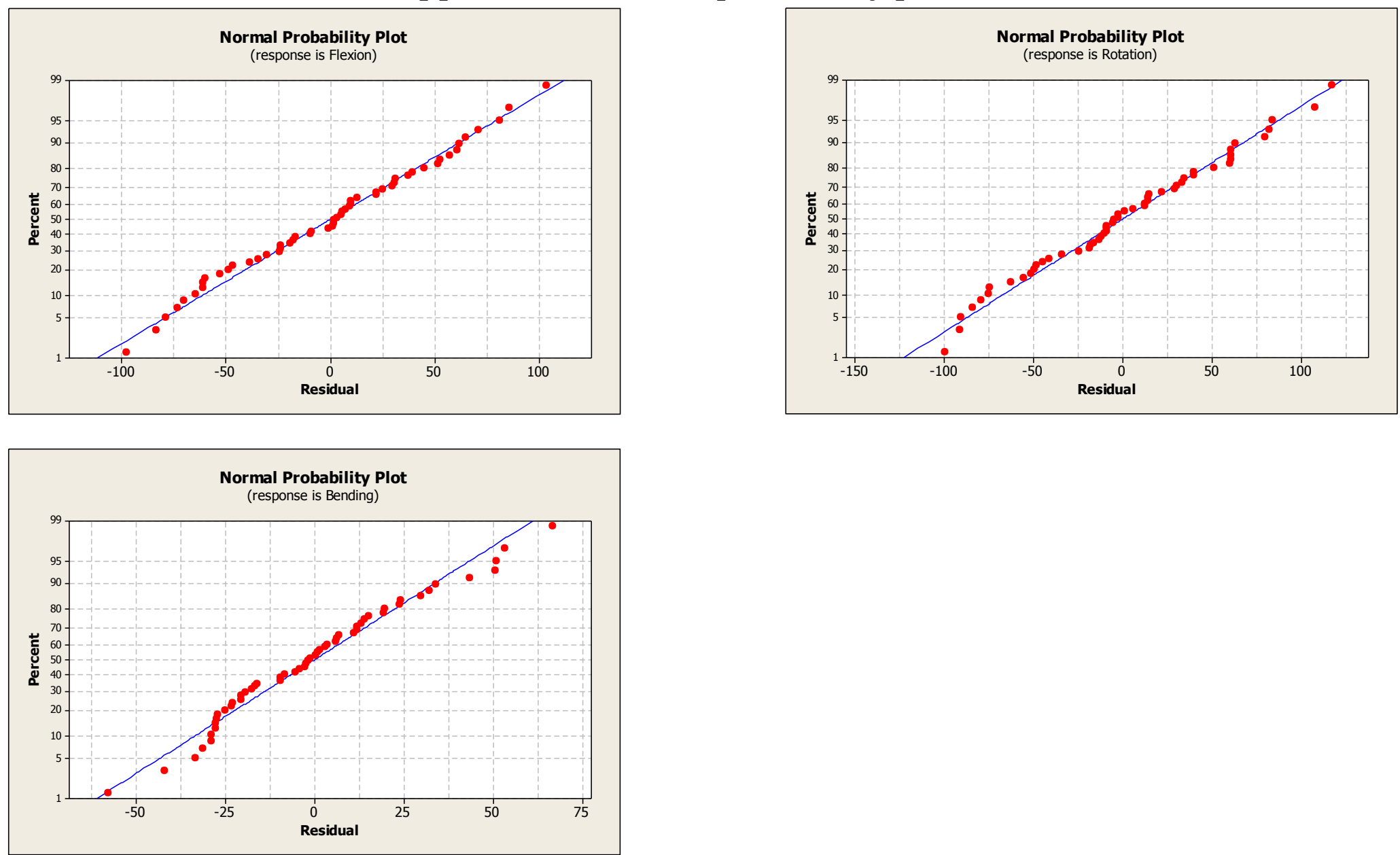


$$
\begin{aligned}
& I= \\
& I Z
\end{aligned}
$$




\section{Appendix D - Raw postural load Data}

\begin{tabular}{|c|c|c|c|c|c|}
\hline Sub & Monitor & task & Flexion & Bending & Rotation \\
\hline & 1 Dual & Typing & 539.2756 & 223.6197 & 698.2463 \\
\hline & 1 Dual & $S \& F$ & 241.8137 & 115.2131 & 551.676 \\
\hline & 1 Dual & Reading & 438.993 & 169.5641 & 650.4147 \\
\hline & 1 Single & Typing & 526.1095 & 125.5194 & 608.3698 \\
\hline & 1 Single & S\&F & 268.8772 & 100.4947 & 393.0037 \\
\hline & 1 Single & Reading & 462.2836 & 100.0514 & 374.0855 \\
\hline & 2 Dual & Typing & 479.7857 & 113.0653 & 385.9269 \\
\hline & 2 Dual & S\&F & 351.735 & 160.4544 & 344.5852 \\
\hline & 2 Dual & Reading & 379.844 & . 111.3424 & 352.3384 \\
\hline & 2 Single & Typing & 326.8935 & 105.7758 & 225.1329 \\
\hline & 2 Single & $S \& F$ & 178.244 & 104.3325 & 194.0794 \\
\hline & 2 Single & Reading & 102.1925 & 100.4132 & 188.7258 \\
\hline & 3 Dual & Typing & 326.8935 & 105.7758 & 225.1329 \\
\hline & 3 Dual & S\&F & 226.626 & 124.099 & 115.3692 \\
\hline & 3 Dual & Reading & 207.1534 & 101.6854 & 505.757 \\
\hline & 3 Single & Typing & 528.1776 & 192.5133 & 206.5592 \\
\hline & 3 Single & $S \& F$ & 178.244 & 104.3325 & 194.0794 \\
\hline & 3 Single & Reading & 102.1925 & 100.4132 & 188.7258 \\
\hline & 4 Dual & Typing & 160.5967 & 100 & 228.9957 \\
\hline & 4 Dual & S\&F & 234.1059 & 103.9037 & 351.9133 \\
\hline & 4 Dual & Reading & 134.6288 & 101.7932 & 132.8407 \\
\hline & 4 Single & Typing & 324.9031 & 120.0017 & 206.3895 \\
\hline & 4 Single & $S \& F$ & 151.0269 & 101.8155 & 151.3424 \\
\hline & 4 Single & Reading & 168.9234 & 103.4836 & 178.6371 \\
\hline & 5 Dual & Typing & 488.0422 & 236.7212 & 436.5986 \\
\hline & 5 Dual & $S \& F$ & 287.7508 & 111.3128 & 345.8764 \\
\hline & 5 Dual & Reading & 292.4576 & 160.7743 & 202.0657 \\
\hline & 5 Single & Typing & 488.0422 & 236.7212 & 436.5986 \\
\hline & 5 Single & S\&F & 398.3535 & 136.2574 & 193.2068 \\
\hline & 5 Single & Reading & 424.6671 & 127.459 & 222.7378 \\
\hline & 6 Dual & Typing & 386.5095 & 154.9237 & 332.4207 \\
\hline & 6 Dual & S\&F & 190.5755 & 122.1706 & 340.9196 \\
\hline & 6 Dual & Reading & 142.8666 & 104.0436 & 240.1127 \\
\hline & 6 Single & Typing & 347.497 & 151.4332 & 254.3871 \\
\hline & 6 Single & S\&F & 246.0769 & 127.2969 & 150.4325 \\
\hline & 6 Single & Reading & 170.4143 & 124.6027 & 167.6061 \\
\hline & 7 Dual & Typing & 456.2575 & 195.6077 & 330.0789 \\
\hline & 7 Dual & $S \& F$ & 395.4008 & 162.3736 & 364.4407 \\
\hline & 7 Dual & Reading & 327.7898 & 203.7647 & 270.3236 \\
\hline & 7 Single & Typing & 455.2512 & 199.6417 & 332.0915 \\
\hline & 7 Single & S\&F & 361.3789 & 156.4835 & 181.7752 \\
\hline & 7 Single & Reading & 373.2659 & 107.4764 & 136.633 \\
\hline & 8 Dual & Typing & 349.4703 & 110.0189 & 261.0801 \\
\hline & 8 Dual & S\&F & 137.962 & 154.8792 & 377.3729 \\
\hline & 8 Dual & Reading & 128.6877 & 104.4554 & 174.2665 \\
\hline & 8 Single & Typing & 294.1248 & 108.5273 & 248.1485 \\
\hline & 8 Single & S\&F & 132.263 & 118.6781 & 186.0387 \\
\hline & 8 Single & Reading & 133.7213 & 122.1003 & 167.3197 \\
\hline & 9 Dual & Typing & 342.4499 & 107.9307 & 280.1063 \\
\hline & 9 Dual & S\&F & 139.2069 & 142.3528 & 283.639 \\
\hline & 9 Dual & Reading & 212.4539 & 137.2546 & 103.0554 \\
\hline & 9 Single & Typing & 378.7999 & 105.9386 & 236.3209 \\
\hline & 9 Single & S\&F & 173.1272 & 100.733 & 197.0797 \\
\hline & 9 Single & Reading & 139.275 & 108.7358 & 195.3458 \\
\hline
\end{tabular}




\section{Appendix E - Raw normalized muscle activity data}

\begin{tabular}{|c|c|c|c|c|c|c|c|c|c|c|c|c|}
\hline \multirow{2}{*}{ Sub } & \multirow{2}{*}{$\begin{array}{l}\text { Monitor } \\
1 \text { Dual }\end{array}$} & \multirow{2}{*}{$\begin{array}{l}\text { Task } \\
\text { S\&F }\end{array}$} & \multirow{2}{*}{$\begin{array}{l}\text { R_SCM } \\
2.677892\end{array}$} & \multirow{2}{*}{$\frac{\text { L_SCM }}{2.511719}$} & \multicolumn{2}{|c|}{ R_TRP UprL_TRP Upr Sub } & \multirow{2}{*}{$\begin{array}{l}\text { Monitor } \\
5 \text { Dual }\end{array}$} & \multirow{2}{*}{$\begin{array}{l}\text { Task } \\
\text { S\&F }\end{array}$} & \multirow[t]{2}{*}{ R_SCM } & \multirow[t]{2}{*}{ L_SCM } & \multicolumn{2}{|c|}{ R_TRP Up L_TRP Upp } \\
\hline & & & & & 4.371333 & 4.809583 & & & & & & \\
\hline & 1 Dual & Reading & 2.021467 & 2.265471 & 2.645801 & 5.115786 & 5 Dual & Reading & 2.553431 & 1.99492 & 2.110903 & 4.069806 \\
\hline & 1 Dual & Typing & 3.075546 & 2.530543 & 5.549921 & 7.028039 & 5 Dual & Typing & 4.567021 & 2.225479 & 5.789625 & 8.419491 \\
\hline & 1 Single & $S \& F$ & 2.245646 & 2.161161 & 3.822456 & & 5 Single & S\&F & 3.144334 & 2.576339 & 3.354804 & 7.628425 \\
\hline & 1 Single & Reading & 1.8126 & 2.193106 & 2.656439 & & 5 Single & Reading & 2.05695 & 1.794539 & 1.909191 & 5.234522 \\
\hline & 1 Single & Typing & 3.225605 & 2.460687 & 5.848764 & & 5 Single & Typing & 3.006795 & 2.643089 & 4.382424 & 7.460291 \\
\hline & 2 Dual & S\&F & 4.571389 & 4.06283 & 4.704291 & 6.823976 & 6 Dual & S\&F & 3.721614 & 2.960964 & 3.258959 & 3.334486 \\
\hline & 2 Dual & Reading & 4.865191 & 2.411885 & 4.128721 & 4.337475 & 6 Dual & Reading & 3.272334 & 1.862275 & 1.874055 & 4.266518 \\
\hline & 2 Dual & Typing & 5.844125 & 3.497386 & 7.299399 & 8.962341 & 6 Dual & Typing & 4.249273 & 4.162593 & 4.187357 & 6.096837 \\
\hline & 2 Single & S\&F & 3.18459 & 4.015749 & 4.699395 & 6.776032 & 6 Single & S\&F & 3.810747 & 4.492091 & 3.643453 & 5.469254 \\
\hline & 2 Single & Reading & 3.168497 & 3.070286 & 4.604151 & 4.845924 & 6 Single & Reading & 3.367199 & 1.73318 & 1.704109 & 4.388036 \\
\hline & 2 Single & Typing & & & & & 6 Single & Typing & 4.800835 & 4.183443 & 4.102403 & 5.841185 \\
\hline & 3 Dual & S\&F & 3.462202 & 2.530629 & 4.497519 & 7.925113 & 7 Dual & S\&F & 4.409333 & 3.727401 & 2.048878 & 6.37721 \\
\hline & 3 Dual & Reading & 2.601437 & 2.572287 & 2.273951 & 5.349254 & 7 Dual & Reading & 4.454571 & 2.499156 & 1.812101 & 5.359921 \\
\hline & 3 Dual & Typing & 4.05351 & 3.292411 & 5.582499 & 9.701241 & 7 Dual & Typing & 5.243528 & 5.806243 & 3.979366 & 7.343658 \\
\hline & 3 Single & $S \& F$ & 2.81597 & 2.240449 & 3.434357 & 6.238412 & 7 Single & S\&F & 5.32166 & 4.727627 & 3.80322 & 7.476986 \\
\hline & 3 Single & Reading & 2.616735 & 2.025101 & 2.183144 & 5.343034 & 7 Single & Reading & 3.800015 & 2.723835 & 2.376252 & 5.055776 \\
\hline & 3 Single & Typing & 2.860075 & 2.172641 & 4.000013 & 6.281623 & 7 Single & Typing & 5.421234 & 4.573472 & 2.396945 & 8.622666 \\
\hline & 4 Dual & S\&F & 5.606843 & 4.775574 & 5.692976 & 7.171044 & 8 Dual & S\&F & 4.892431 & 4.887001 & 3.374859 & 3.976679 \\
\hline & 4 Dual & Reading & 5.185573 & 3.141427 & 3.559634 & 4.559609 & 8 Dual & Reading & 4.466292 & 4.428775 & 2.490735 & 3.639308 \\
\hline & 4 Dual & Typing & 5.620531 & 3.072522 & 7.328192 & 7.415003 & 8 Dual & Typing & 4.169479 & 5.947403 & 3.234373 & 4.159437 \\
\hline & 4 Single & S\&F & 3.508143 & 5.225264 & 5.066518 & 7.249592 & 8 Single & S\&F & 3.304116 & 4.624738 & 2.564763 & 3.765882 \\
\hline & 4 Single & Reading & 2.81373 & 3.653903 & 4.703355 & 6.556173 & 8 Single & Reading & & & & \\
\hline & 4 Single & Typing & 4.436989 & 3.491144 & 6.314232 & 8.226285 & 8 Single & Typing & 3.834795 & 4.719432 & 2.499444 & 3.999049 \\
\hline & & & & & & & 9 Dual & S\&F & 2.64676 & 2.79841 & 2.314673 & 3.308524 \\
\hline & & & & & & & 9 Dual & Reading & 3.632328 & 2.78214 & 1.524183 & 2.316989 \\
\hline & & & & & & & 9 Dual & Typing & 3.193838 & 2.977638 & 2.454484 & 3.961143 \\
\hline & & & & & & & 9 Single & S\&F & 2.318103 & 3.339168 & 2.046069 & 4.669643 \\
\hline & & & & & & & 9 Single & Reading & 1.61275 & 2.948624 & 2.068801 & 3.167394 \\
\hline & & & & & & & 9 Single & Typing & 2.738359 & 3.141586 & 2.028602 & 4.853644 \\
\hline
\end{tabular}

